\title{
Solar Energy as an Altemate Energy Source to Mixed Oxide Fuels in Light-Water Cooled Reactors
}

\author{
H. W. Bertini
}

Prepared for the U.S. Nuclear Regulatory Commission

Office of Nuclear Reactor Regulation Under Interagency Agreement ERDA 40-544-75 

Contract No. H-7405-eng-26

Engineering Technology Division

SOLAR ENERGY AS AN ALTERNATE ENERGY SOURCE TO MIXED OXIDE FUELS IN LIGHT-WATER COOLED REACTORS

H. W. Bertini

Manuscript Completed: June 30, 1977

Date Published: August 1977

NOTICE: This document contains information of a preliminary nature and was prepared primarily for internal use at the Oak RIdge National Laboratory. It is subject to revision or correction and therefore does not represent a final report.

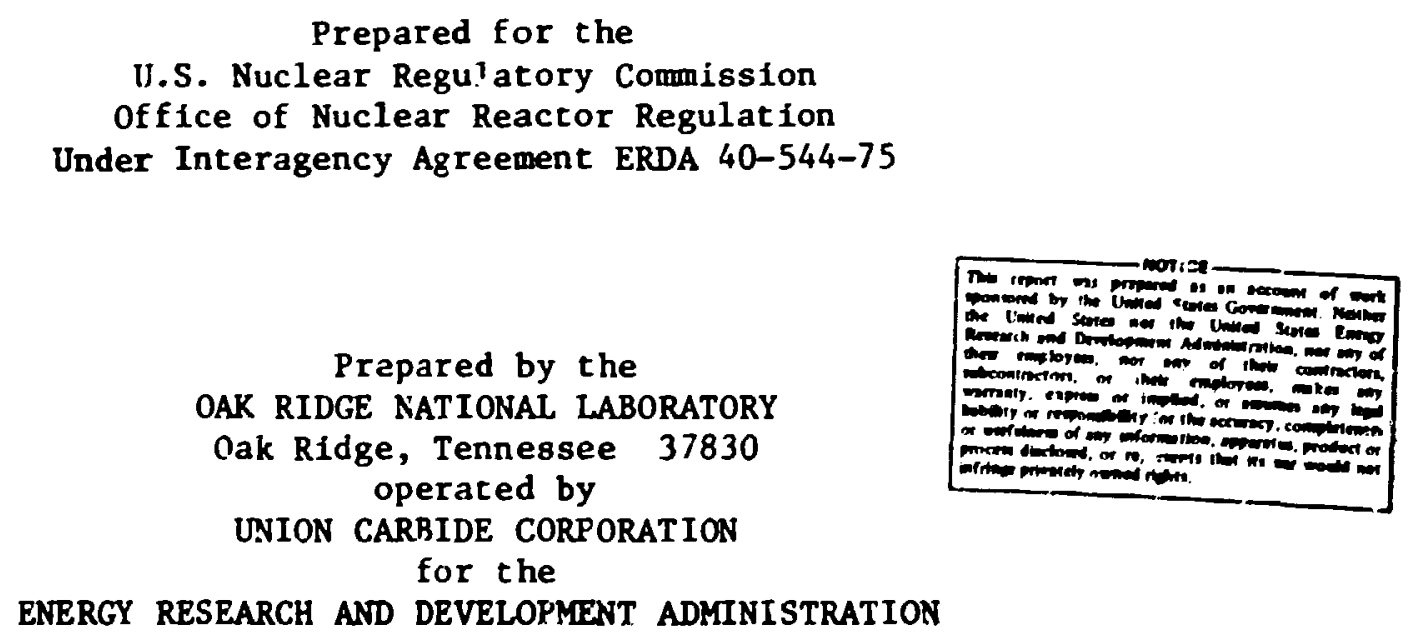


Table of Contents

Page

ACRMONLEDGEAMTS $\ldots \ldots \ldots \ldots \ldots \ldots \ldots \ldots \ldots \ldots \ldots \ldots \ldots \ldots \ldots$

ABSTRACT $\ldots \ldots \ldots \ldots \ldots \ldots \ldots \ldots \ldots \ldots \ldots \ldots \ldots \ldots \ldots \ldots \ldots \ldots$

INTRODUCTION $\ldots \ldots \ldots \ldots \ldots \ldots \ldots \ldots \ldots \ldots \ldots \ldots \ldots \ldots \ldots \ldots \ldots$

BRIEF DESCRIPTIOAS OF THE VARIOUS SOLAR SYSTEMS ......... 2

Heating and Cooling $\ldots \ldots \ldots \ldots \ldots \ldots \ldots \ldots \ldots \ldots \ldots \ldots \ldots$ 2

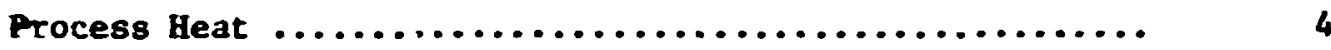

Solar Electric Systens $\ldots \ldots \ldots \ldots \ldots \ldots \ldots \ldots \ldots \ldots \ldots \ldots \ldots . . \ldots$

Solar thermal (central receiver) ................. 9

Solar thermal (distributed collector) .............. 9

Photovoltalc cells .......................... 14

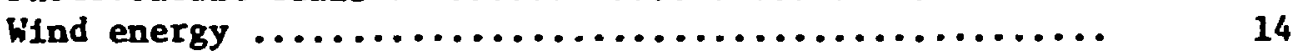

Ocean thermal conversion $\ldots \ldots \ldots \ldots \ldots \ldots \ldots \ldots \ldots \ldots \ldots . \ldots \ldots$

Fuels from organic Materials .................... 19

PROJECTED SOLAR ENERGY UTILIZATION IN THE YEAR $2000 \ldots \ldots \ldots .19$

POTENTIAL SOLAR SUBSTITUTION FOR BASE LOAD LWR's ........ 24

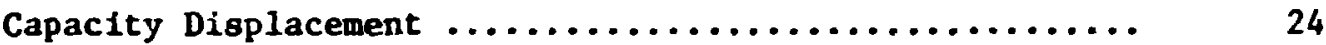

Economic Considerations ....................... 27

Effect of recycling option on solar economics ........ 27

Projected solar costs ........................ 28

LAND USE OF SOLAR VS NUCLEAR $\ldots \ldots \ldots \ldots \ldots \ldots \ldots \ldots \ldots \ldots \ldots \ldots$

Solar therwal (Central Receiver) ................ 30

Photovoltalc .............................. 31

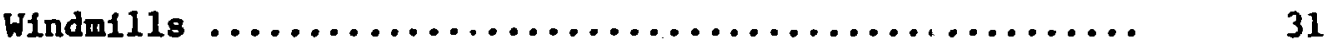

RELATED SUBJECTS ON SOLAR ENERGY $\ldots \ldots \ldots \ldots \ldots \ldots \ldots \ldots \ldots \ldots \ldots$

Technical Problems ......................... 33

Heating and cooling $\ldots \ldots \ldots \ldots \ldots \ldots \ldots \ldots \ldots \ldots \ldots \ldots . \ldots \ldots$

Process heat $. \ldots \ldots \ldots \ldots \ldots \ldots \ldots \ldots \ldots \ldots \ldots \ldots \ldots \ldots . \ldots \ldots$

Solar thermal conversion to electricity ............ 33

Photovoltaic .............................. 33

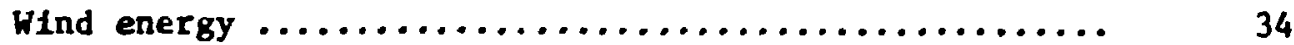

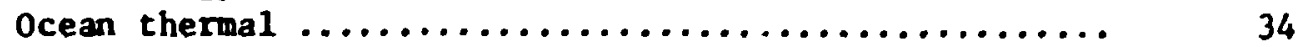

Environmental Problems ........................ 34 
BLANK PAGE 
Social and Institutionai Problems .................

Conclusion $\ldots \ldots \ldots \ldots \ldots \ldots \ldots \ldots \ldots \ldots \ldots \ldots \ldots \ldots \ldots \ldots \ldots$

APPENDIX $\ldots \ldots \ldots \ldots \ldots \ldots \ldots \ldots \ldots \ldots \ldots \ldots \ldots \ldots \ldots \ldots \ldots \ldots$ 36

REPEREAICES 


\section{ACKNOWLEDG:ENTS}

This report was prepared under the supervision of Truman D. Anderson, whose guidance is gratefully acknowledged. Also, the considerable cooperation of Steven I. Kaplan in supplying reference material and several helpful discussions is greatly appreciated. 


\title{
SOLAR ETERG AS AN ALTERUATE ERERG SOURCE TO MIXED OXIDE FUELS IN LIGHT-HATER COOLED REACTORS
}

\author{
H. W. Bertin1
}

\section{ABSTRACT}

Supplemental information pertaining to the generic environmental ippact statement on the Pu recycling process for nixed oxide light-water cooled reactors (GESY) was requested from several sources. In partfcular, the role of alternate srurces of energy were to be explored and the inplications of these alternate sources to the question of Pu recycle in LWR's were to be investigated. In this vein, soiar energy as an alternate source is the main subject of this report, along with other inforation related to solar energy. The general conclusion is that solar energy should have little effect on the decisions concerning GESH.

\section{INTRODUCTION}

In the generic environmental impact statement on the use of recycled plutonium for mixed oxide fuels in light-water cooled reactors (GESWO), the assumption is made that the number of light-water cooled reactors (LWR's) in operation by the year 2000 w11 be independent of the choice of fuel cycle option.' Questions ralsed by the hearing board on GESMO regarding this assumption point to the possibility that the number of LWR's might decrease if Pu recycle is not permitted. ${ }^{2}$ A corollary question for impact statement purposes 1s, could this decrease in the number of reactors be ciffet by alternate sources of energy. This study is directed toward that question and to other related questions when solar energy is taken as the altemate energy source, and the study also includes general information pertinent to solar energy as a resource.

As a basis f'r comparison, the decrease in the nuclear capacity by the year 2000, c.te to a negative dectsion on Pu recycle, will be assumed to amount to 5, 10, and $20 \%$ of the nuclear capacity which is presently 
BLANK PAGE 
projected for that time and which was assumed to be independent of the fuel-cycle option utilized. The nuclear capacity in the year 2000 is estimated to be 507,000 $\mathrm{M}(\mathrm{e}),{ }^{3}$ therefore the decrease in nuclear capac1ty w111 be taken as 25,350; 50,700; or 101,400 MA(e).

\section{BRIEF DESCRIPTIOI OF THE VARIOUS SOLAR SYSTEMS}

There is sufficient energy in the insolation from the sun to supply all of the present United States energy needs even if only a small fraction of the United States land area is utilized for the capture of the sun's radiation. ${ }^{4}$ The two major problems with solar energy as a resource are that it is diffuse and it is intermittent. Large collector areas are required because of the diffuseness, and the intermitiency causes problems because the energy is not readily available on demand. Some of the ramifications of these shortcomings are discussed in subsequent sections. Figure 1 shows the average distribution of insolation over the United States. ${ }^{5}$ Various systems that would utilize the energy from the sun have been proposed and they will 3 described brlefly in general cerms.

\section{Heating and Cooling}

Systems designed to heat and cool bulldings have been proposed and some have been constructed. A common type is a flat plate collector which consists of a pair of closely spaced flat metal plates, welded on the sides with headers at each end. A liquid, which can be water or a solution of antifreeze, passes through the headers and flows between the metal plates. The upper surface of the metal plate is coated with a blackened material to absorb the sun's rays, and the plates are boxed with insulation on the bottom and with one or two transparent glass plates or other suitable material on the top. The functions of the plates are to utilize the greenhouse effect, to reduce heat losses from convection, and to protect the blackened metal surfaces. This boxed collector 18 placed on the south-facing roof or walls of the building. 


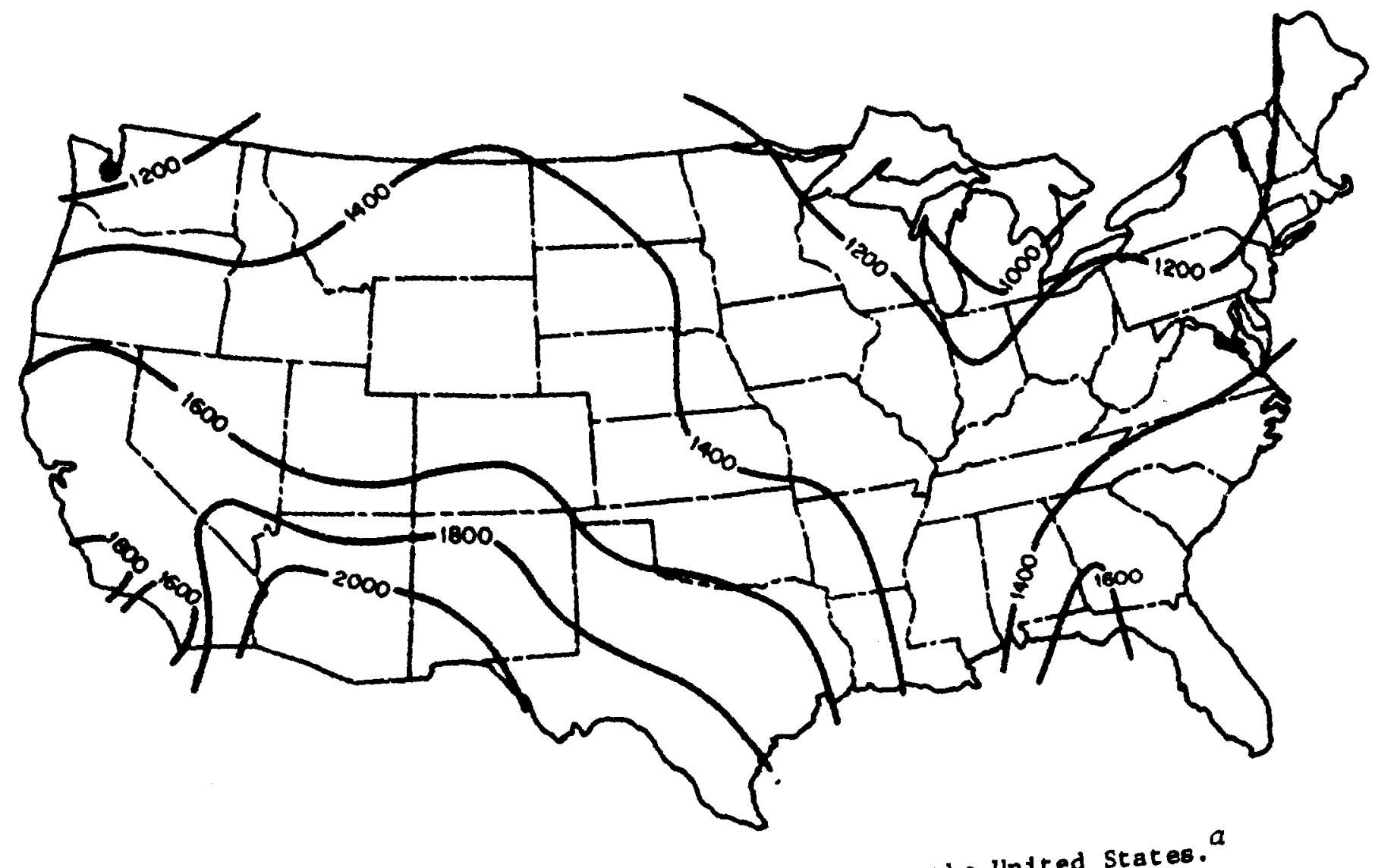

F18. 1. Distribution of golar en

a figures give solar heat in btu/ft per average day 
The liquid is pumped from a storage tank through the collector where it picks up heat and then flows back to the storage tank. The heated Iiquid in the tank serve, as a source of heat for the heating and cooling requirements of the bulliting. The collector and storage tank are shown In F 1 g. 2, and a schematic diagran of the entire systen is illustrated in Fig. 3 .

Temperatures attainable by simple flat plate collectors $290^{\circ} \mathrm{C}$ ( $190^{\circ} \mathrm{F}$ ) are adequate for heating but generally inadequate for cooling. The temperaturis required for common $\mathrm{LiBr}$ air conditioners are ${ }^{\circ} 120^{\circ} \mathrm{C}$ $\left(\sim 250^{\circ} \mathrm{F}\right)$. Varicus schewes have been studied to raise the temperature such as utflizing concentrators of the sun's rays and substituting selective absorbers in place of the blackened surface. The concentrators focus the sun's rajs and have the disadvantage of utilizing only the direct rays from the sun. The diffuse component of the insolaticn cannot be used. They must alsc track the sun which adds to the courplextty of the system. The selective ibsorbers capture both the diffuse and direct radiation, and they are designed to be highly absorptive in the peak region of the incident solar spectrum and highly reflective in the much longer wave lengtin region of the spectrum emitted by the heated collector. Th1s is shown in F1g. 4, and the layers of two sample selective absorbers are shown in F1g. 5 (not to scale).

Research, development and demonstration (RD\&D) for the heating and cooling of bulldings is proceeding at a moderate pace.

\section{$\underline{\text { Process Heat }}$}

The term process heat refers to the generally low-temperature hot air and hot water requirements for industry and agriculture. Flat plate collectors have been studied fcr thelr application in this area.

Another approach is the use of solar ponds, which are shallow treaches dug in the earth. The trenches are made impervious to water leakage by coating their inner surfaces with tar, and they are covered with one or two transparent plastic sheets. The trenches are filled wth plain water or a saline solution, and they are connected to a hot $\ldots$ 


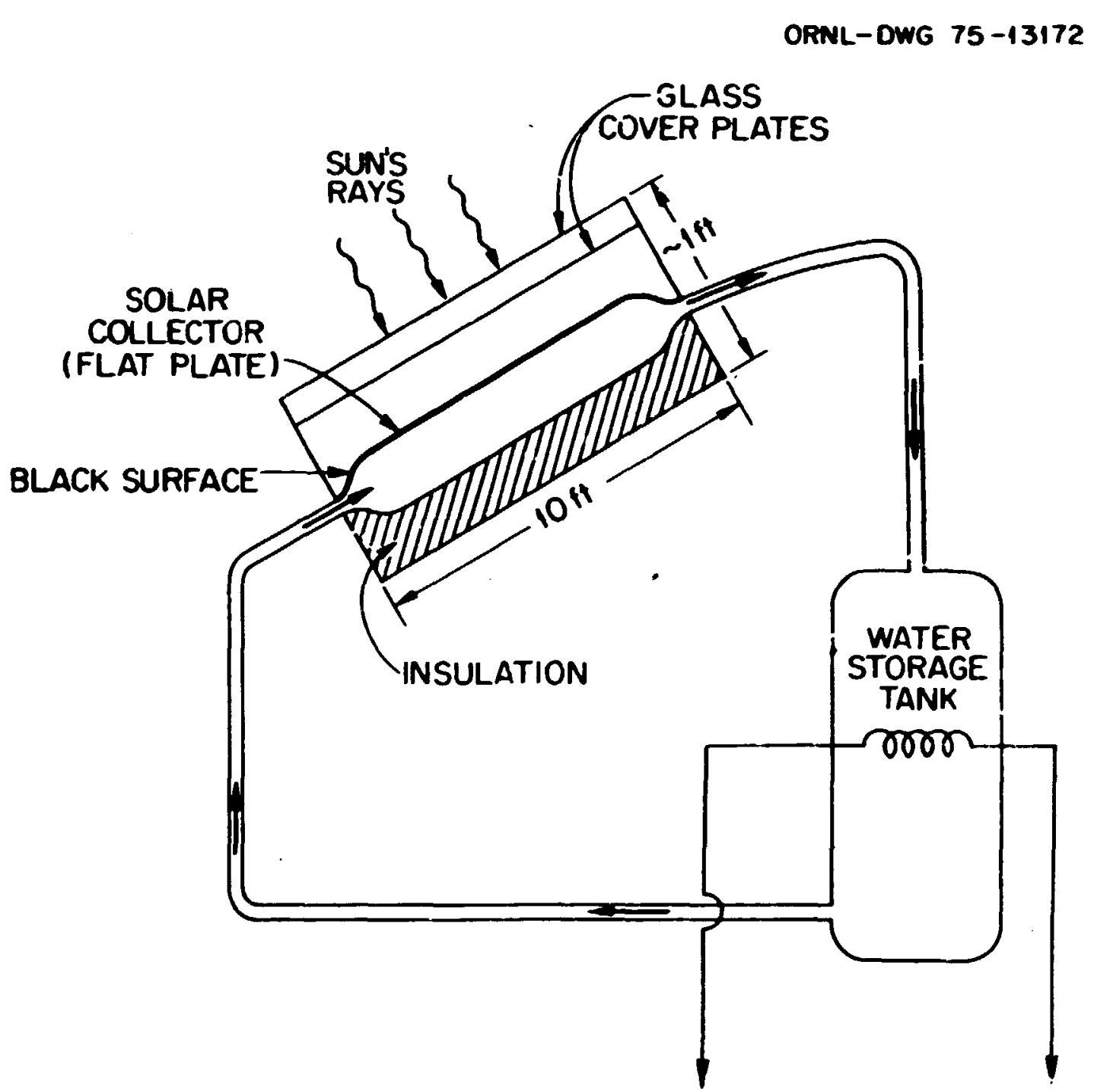

HE ATING, AIR CONDITIONING OF BUILDINGS

Fig. 2. Collector and Storage Tank. 


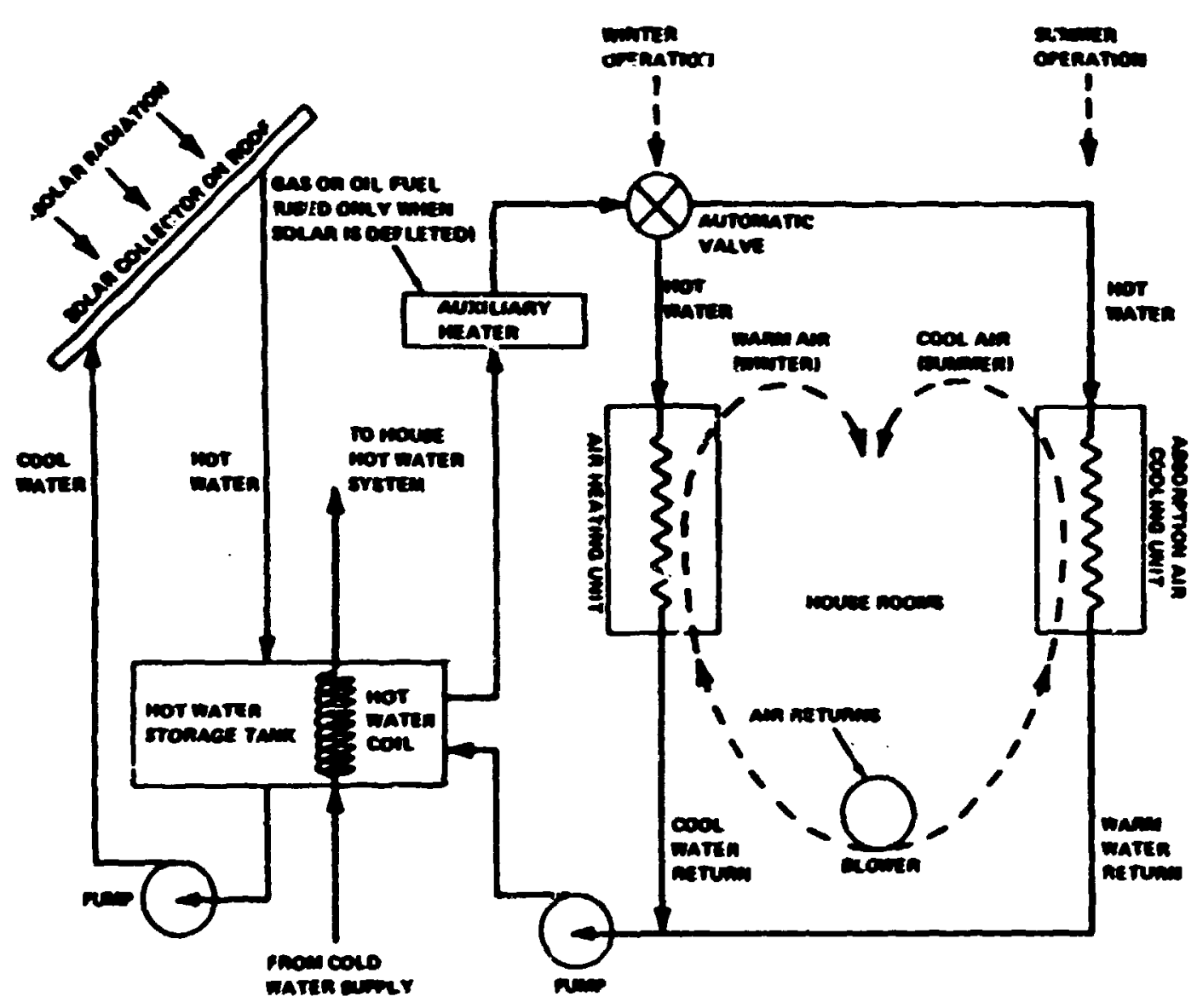

Fig. 3. Schematic of regidential heating and cooling with solar energy - one alternative. 


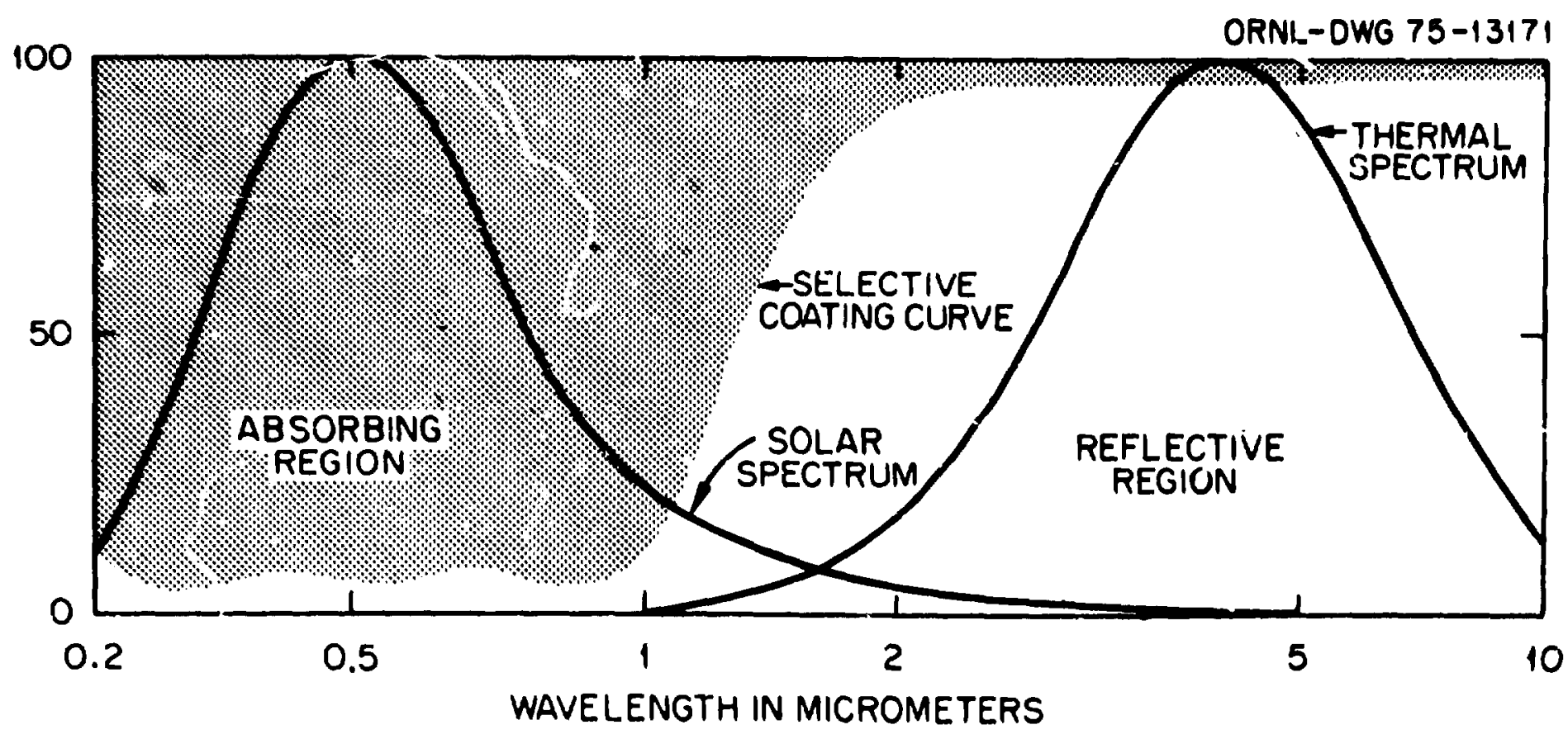

F18. 4. Spectra of Incomine solar radiation and thermal reradiation from a heated surface. A selective coating captures the energy in sunlight ty having a high absorptivity to visible light tut a low enissivity (high reflectivity) to Infrared light. 


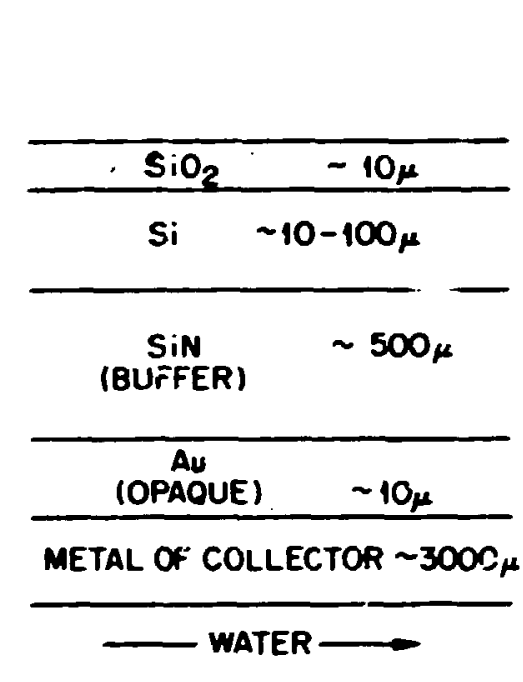

BULK ABSORBER

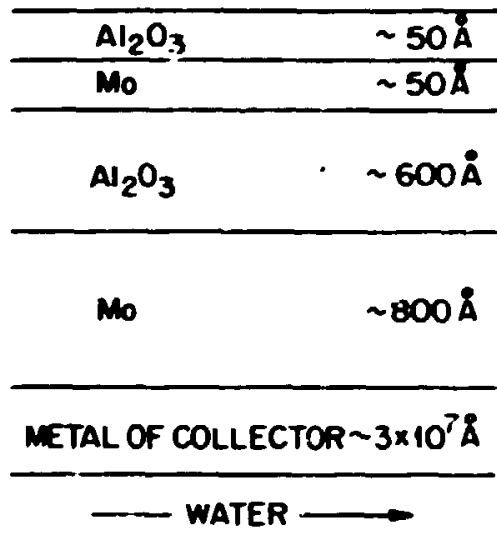

INTERFERENCE FILM ABSORBER

F1g. 5. Examples of selective abscrbers. 
water storage tank, which serves as the source of process heat. The radiation from the sum passes through the plastic sheets and is absorbed by the liquid in the trench or by the tar coatings on the inner trench surfaces, thus heating the ilquid.

The simplicity of thic approach is offset by the cost of the land wiltch must be available for the trenches.

\section{Solar Electric Systems}

Solar Thermal (Central Receiver)

This, and the system described next, is designed as a centralstation electric power plant. Each system is designed to replace the boiler in a relatively standard central station electric power plant. The components of such a power plant are illustrated schematically in Fig. 6. The central receiver system consists of a vast field of heliostats, located at ground level, that reflect the rays from the sun into the bottom of a boller which is perched on a high tower. The individual hellostats are servo-controlled to track the sun. One concept ${ }^{6}$ of such a system is fllustrated in Fig. 7, and a sectional view of a boiler is shown in Fig. 8. The technical problems associated with these systems are described in a subsequent section.

The central receiver has a relative advantage over the distributed collector (described next) in that higher temperatures can be attained. A 5 M(e) demonstration plant is under construction at Sandia, New Mexico.

\section{Solar Thermal (Distributed Collector)}

The distributed collector syetem differs from the central receiver In that all components are at ground level and an alternate focusing method is used. The system consists of individual parabolic-shaped troughs that reflect the rays of the sun onto a pipe located at the focal point of the farabola. The pipe carries the flid which is heated as it passes throus, h. The individual collectors must be servo-controlled to track the sun. One approach ${ }^{7}$ is 1llustrated in Pig. 9. 
ORNL-DWG 75-13169

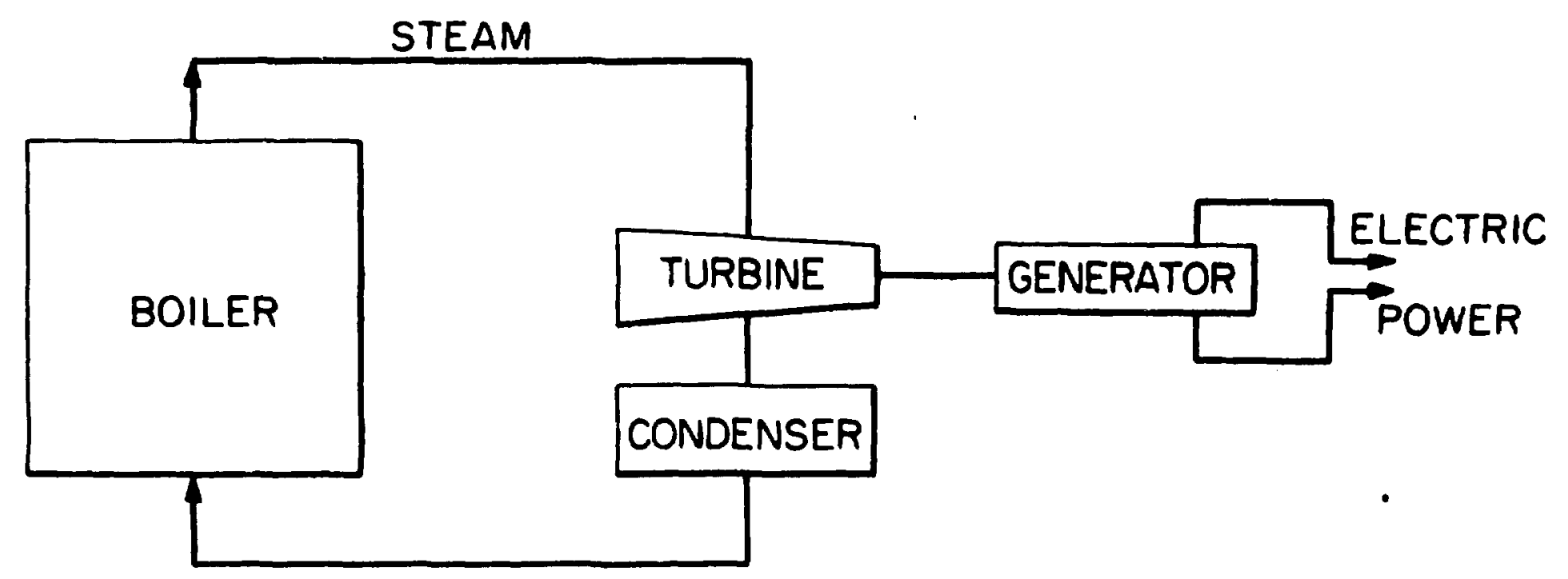

F18. 6. Schematic diagram of a typlcal central-station electricpower plant. 


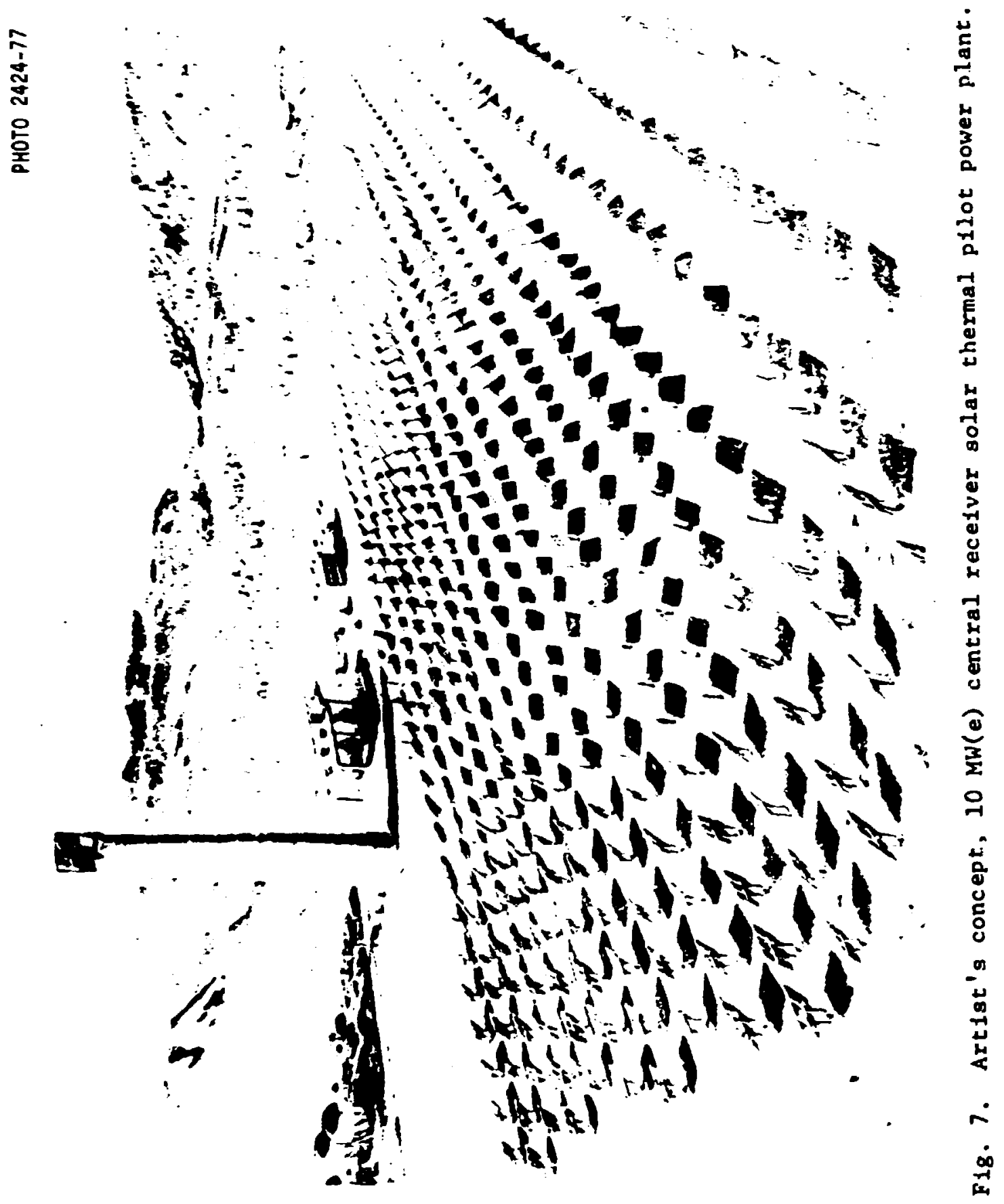




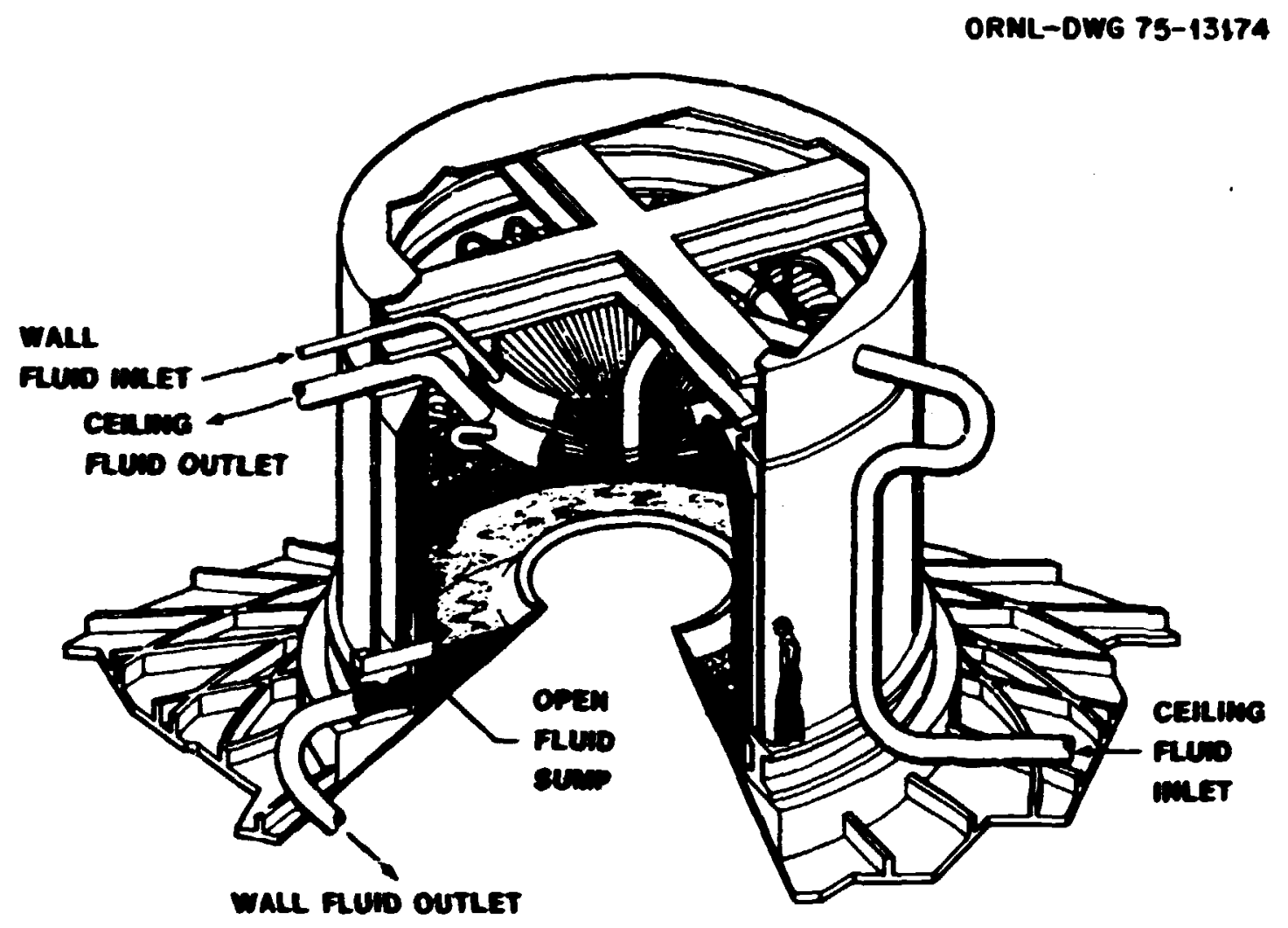

H1. 8. Optical cavity absorber. 


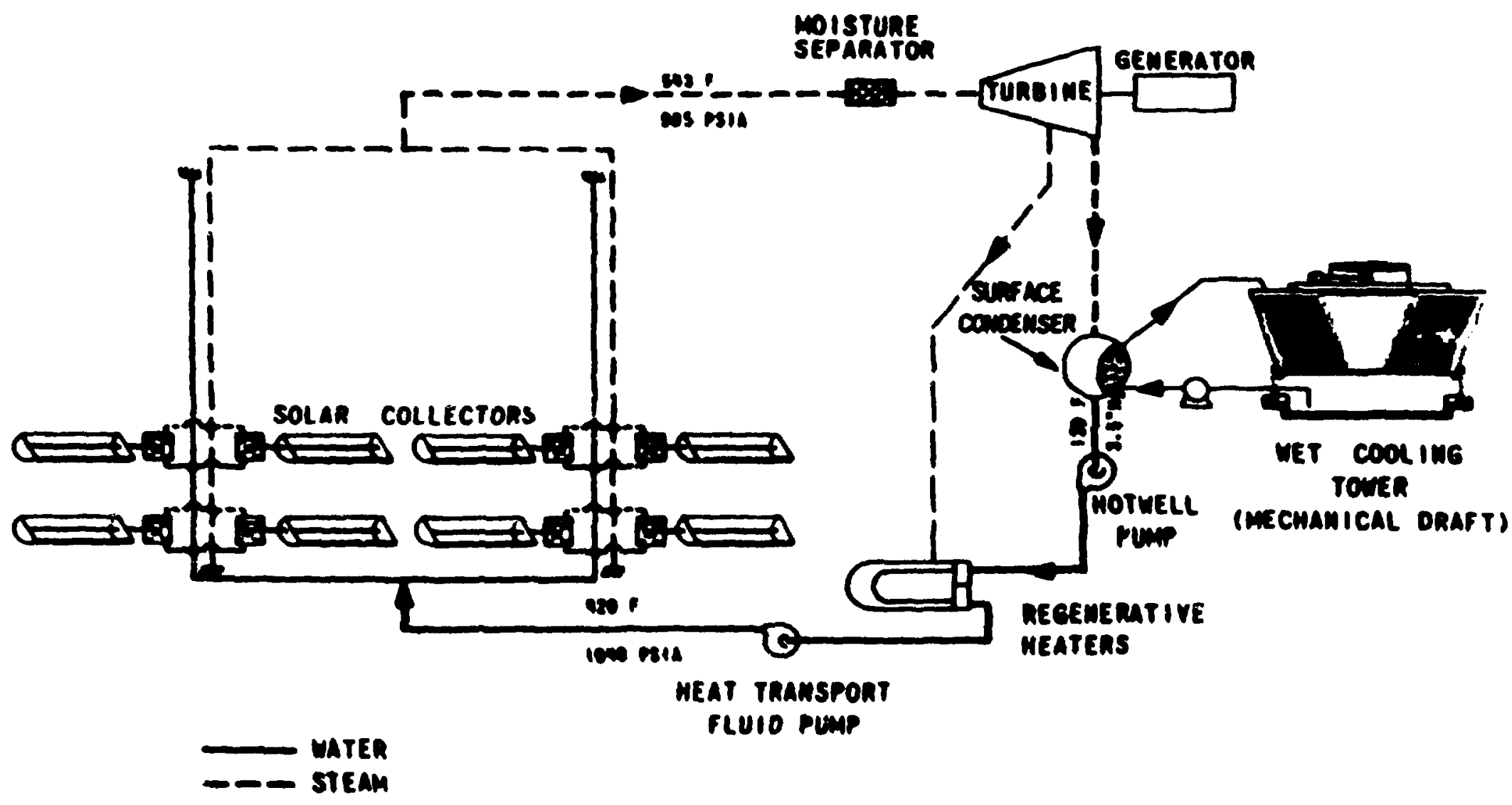

F1g. 9. Parabolic trough collector with heat pipe and steam generator. 
In general, the temperatures attafnable by these systems are lower than those in the central receiver, and hence the llector field must be larger to produce the same power. The prioril, given to the RD\&D of these systems is lower than that for central receivers.

\section{Photovoltalc Cells}

A photovoltaic cell is a solid-state converter of 1 ; ght to electricity. They were utilized extensively in the space program to provide electricity to both manned and unmanned satellites. Then a photon from the sun is absorbed by a photovoltaic cell, the photon creates a free electron and a "hole" in the normal electron sea that exists in the cell. The cell is so constructed that the manuactured inhomogenieties, which were introduced in the crystal-cell structure, create a small electromotive force that drives the free electron and hole in opposite directions. With sun shining on $i t$, the cell can thus produce electricity. Arrays of such cells paced or south-facing roofs or valls of buildings are envisioned to produce electricity for the buildings, and vast array 3 are under consideration for the centrai-station generation of electricity. Pigure 10 shows a conceptual design of a 100-Mi(e) photovoltaic power plant.

The maximum theoretical efficiency of photovoltaic cells is $\sim 20 \%$, and they are currently manufactured at $\sim 10 z$ efficiency. The cost of these cells, $\$ 20-\$ 30,000$ per peak $\mathrm{kW}$ (or atout $\$ 100-\$ 150,000$ per average $\mathrm{kW}$ ) is at least a factor of 100 to 150 times too high to be competitive. New methods in the manufacture of the cells by growing single crystals in continuous ribbons are under development. Innovative manufarturing techniques such as tnis are required to reduce the cost of the cells to competitive levels.

\section{W.ind Energy}

The old concept of the windmill is being renovated in attempts to captite the energy that is available in the wind. A windmill of modern design t.s shown in Fig. 11. 


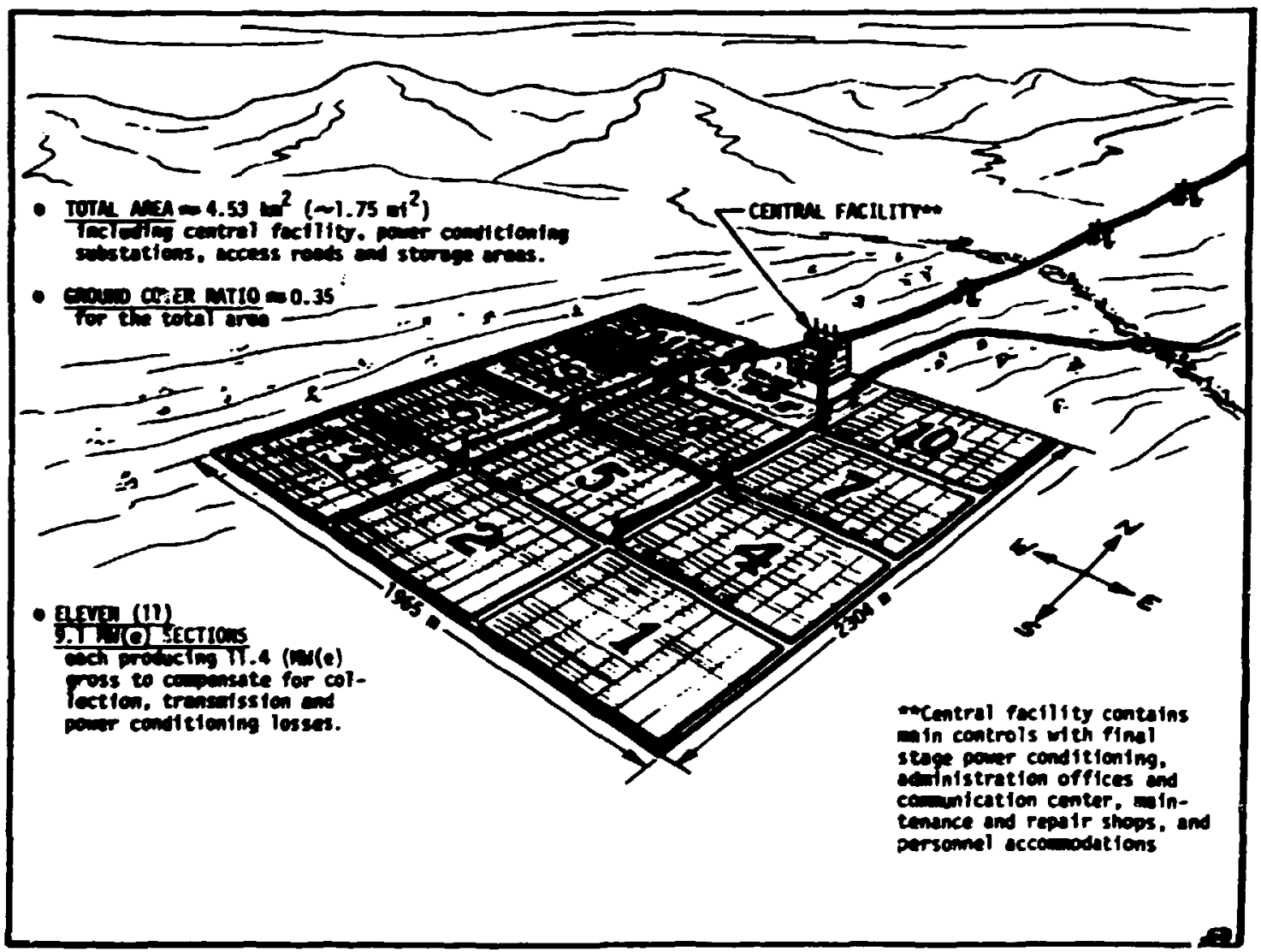

F18. 10. $100 \mathrm{MH}(\mathrm{e}) \star$ photovoltalc power plant.

*Average daytime. 
16

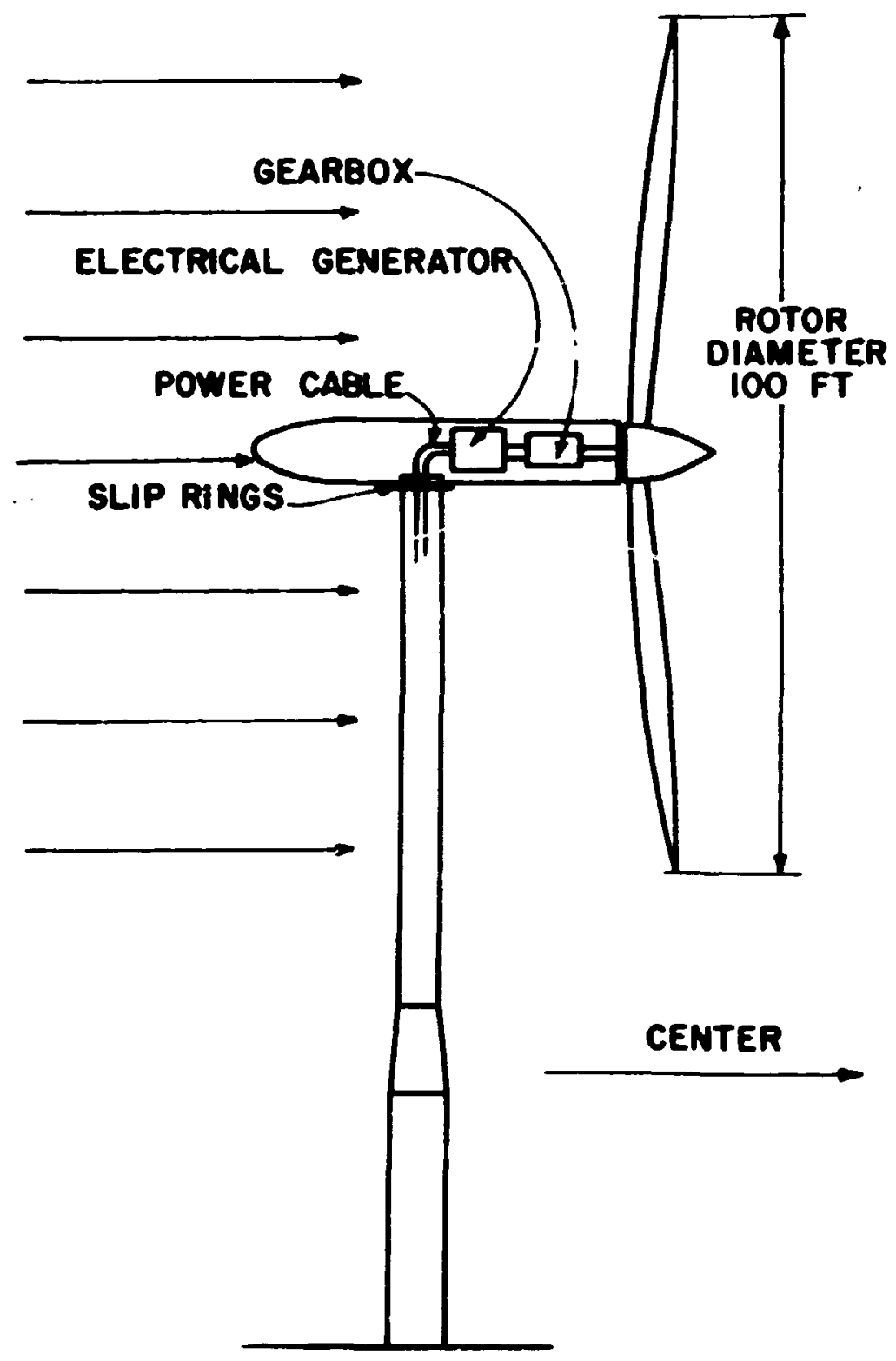

Pig. 11. Typical wind rotor system. 
The energy available from the winds that blow over the United States is significant, and if all of it were utilized it could presumably have supplled ail of our electrical energy needs in 1973." This estimate is considerably higher than wost others, as will be discussed in a following section, but if we are striving for independence of imported fuels then the size of the wind-energy resource is sufficiently substantial to warrant RDSD.

The average capacity factors that result from the intermittency of the wind vary from about 0.6 to 0.7 in the great plains to about 0.4 in various areas of the West Coast and about 0.4 to 0.7 on the East Coast.' Currently, designed windeills reach their rated power in winds of $215-25 \mathrm{mph}$.

A demonstration $100-\mathrm{kW}(\mathrm{e})$ wind machine has been constructed in Plum Brook, Ohfo, with blades that are $125 \mathrm{ft}$ in diameter.

There are plans to construit several other demonstration machines of increasing power before the end of the decade with the machine of maximum power rated between $1-3$ MN(e).

Ocean Thermal Conversion

There is a temperature difference of $220^{\circ} \mathrm{C}\left(\sim 40^{\circ} \mathrm{F}\right)$ between the warm surface waters of the ocean in the equatorial regions of the earth and the deep ocean water. This temperature difference car be utilized to generate electricity. The suitable conditions of warm surface water and cold ocean bottom exist in the Gulf Stream in proximity to the Coast of Florida, and so this potential resource is avallable to the United States. A conceptual design of such a system is shown In Fig. 12.

Because the available temperature difference is so swall these systems must be enormous in order to generate power of any significance. Furthermore, tremendous quantities of warm and cold water must be pumped tinrough the system to produce significant power, and the power used to operate the water pumps represents a substantial fraction ( $15 \%$ ) of the rated power of the system. ${ }^{10}$ The technical problems associated with these systems are discussed in a subsequent section. The ERDA R\&D funding for ocean thermal systems represe.t.s about $10 \%$ of their total funding for solar electric applications. 


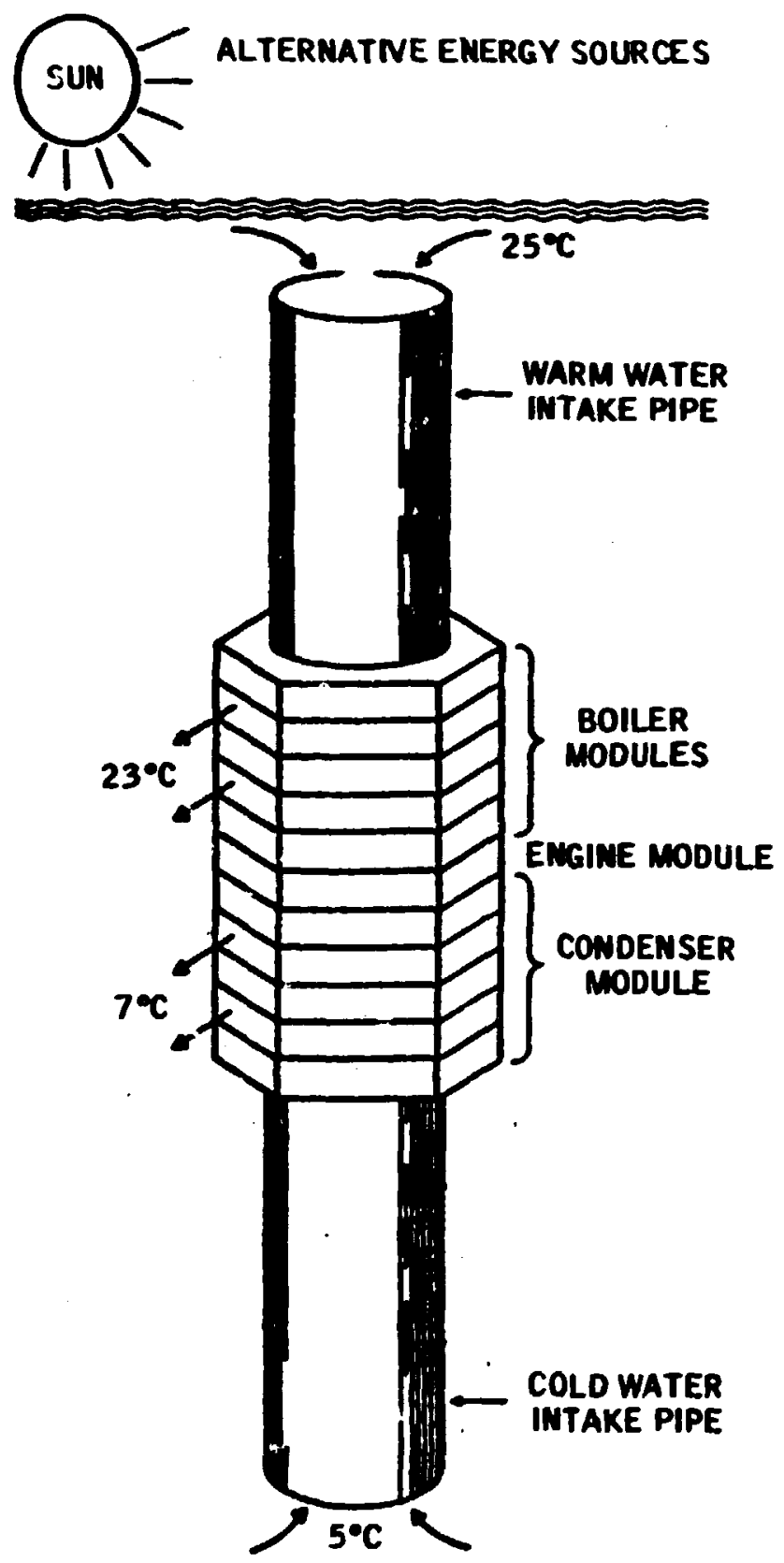

I:s. 12. An art18t's fmpression of a solar power plant ut1lizing the thermal gradient of troplcal oceans. Water at $25^{\circ} \mathrm{C}$ would be taken In at the top and water at $5^{\circ} \mathrm{C}$ would be taken in at the bottom. The difference in temperatures could be used to drive a turbine. The entire device would be neutrally buoyant in several hundred feet of water. 


\section{Fuels from Organic Materials}

The object of the organic materials progras is to convert organic materials to useful fuels. The organic materials can be crops, such as sugar cane and suitable trees, or agricultural wastes (manure) and municipal wastes (garbage and sewerage).

Tisere are three approaches under investigation. The first is hydrogenation and it applies to crops. It involves heating the organic materfal with 60 and steam to about $300^{\circ} \mathrm{C}\left(570^{\circ} \mathrm{F}\right)$ under high pressure $(2100-250 \mathrm{~atm})$. The product is a fairly heavy ofl. The second approach is pyrolysis where the feed material (again crops) is heated at atmospherfc pressure to high cemperatures $\left[\sim 500^{\circ} \mathrm{C}\left(\sim 930^{\circ} \mathrm{F}\right)\right]$ in an oxygen free atmosphere. The products are ofl, a low heat-content gas, and combustible char. The third approach is bio-conversion where the feed material, which can be either waste products or crops, is fermented through bacterial action producing a sludge and useful gases, 1.e., methane. This approach is ut1lized by several cities as a method of waste disposal. R\&D in this area is funded at about half of the level of that for ocean thermal conversion.

PROJECTED SOLAR ENERGY UTILIZATION IN THE YEAR 2000

There is considerable variation in the estimates of the contribution that solar energy might make to our energy needs in the y zar 2000. Several of the more optimistic projections are given in Tabie $I$. It should be pointed out that in all but one of these studies various scenarios were selected in order to achieve the values quoted in the Table. These values were established as goals so that the United States dependence on Imported fuels could be reduced or eliminated. Only one attempt was made to evaluate the likelihood of achieving these goals. ${ }^{11}$ other groups and solar energy experts have more pessimistic opintons of the extent to which solar energy w11 be utilized in the next 25 years. These opinions will be describer below. 
Rather than attept an evaluation of the reasonableness of each prediction, for the purposes of this report all predictions were given equal weight and a siple average for each systen was calculated. These averages are shown in Table $I$. The average values of the estinated contributions are sumarized in Table II along with the fractions of the estimated energy needs for the yedr 2000 that they represent. The resalts indicated that under optinficic assuptions, solar energy utilization aight supply about 72 of the total United States energy needs for the year 2000, and represent about $10 z$ of the total electrical energy capacity for the same year.* However, sone of the United States pioneers In the fleld of solar energy express caution with resfect to the expectation of the ieplenentation of solar energy systens. H. C. Hottel of the Massachusetts Institute of Technology, whose involvement in solar energy research spans a period of over 35 years, states, ${ }^{24}$
"The sun can possibly supply low potential energy for dowestic hot water, house heating, and air conditioning but the effect on the national energy balance cannot but be Insignificant for decades. Solar energy as a source of power has poor prospects of economic significance until the distant future when fossil fuel supplies are several tfmes, and nuclear fuel supplies many times mort expensive than at present [1973]."

And George Löf of Colorado State University, who 18 anoth.er well knisn proponent of solar energy systems and who has, in fact, constructed a solar heated warm air system for his home, states, ${ }^{25}$ (in testimony before the House Confittee on Science and Astronautics),

\footnotetext{
"This cumattee has heard testimony related to the status and prospect = of solar power plants and can ti.erefore apprectate the formidable technical and economic barriers to that application in the near future. in spite of some optimistic claims by enthusiastic proponents of various schemes for solar power generation, objective analysis show that electricity from solar energy will cost at least several tines the current [1973] cost of conventional pciver."
}

*Th1s does not mean that solar energy might displace $10 \%$ of the total electrical generating sapacity. See the next section for a detalled discussion of this point. 
Tabie I. Estieated Solar Energy Installed Capacity for che Year 2000

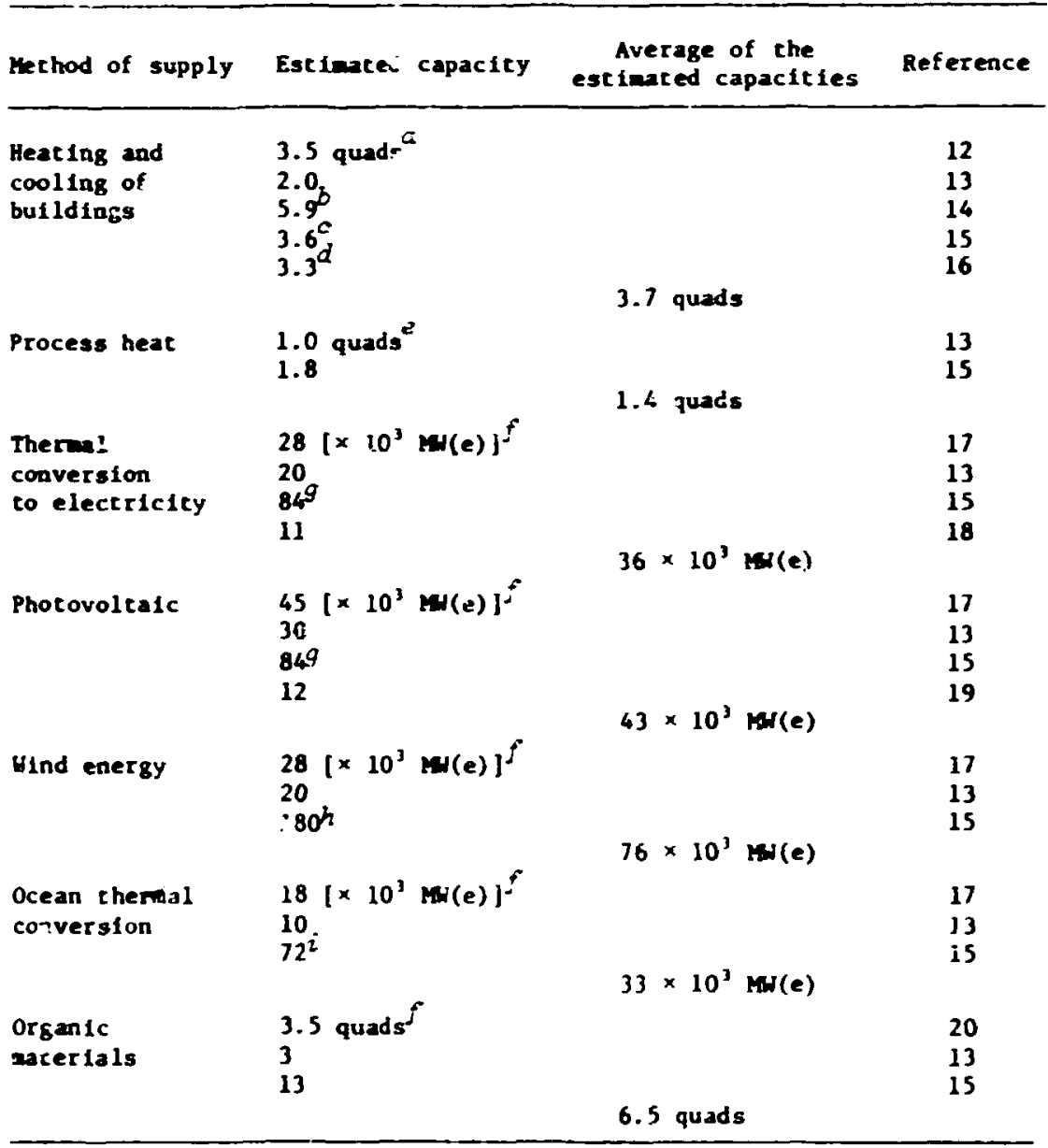

$a_{1}$ quad $=10^{15}$ stu.

Represents the maximum lapact of any scenario considered in ERDA48 (Ref. 12).

Rifer nce 15 reports a value of ?h of the cotal U.S. energy requirements for the year 2000 , but the total estimated energy requirements in Ref. 15 is 180 quads for the year 2000, which 18 higher than the estimated 163 quads in Ref. 21 , and also higher than 150 quads which is a calculated extrapolat ion to the year 2000 (assining ? $2.8 \%$ growth rate) frow the data in Ref. 22.

Calcuiated from the estimaced $2 \pi$ of the nation's energy requirenents for the year 2000 . This number was taken to be 163 quads (Ref. 21).

eThe sua of agricultural and industrial applications.

The average of the range of values quoted.

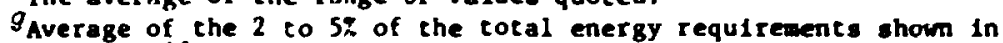
Ref. $15\left(\mathrm{~h} \times 10^{12}\right.$ watts). A toz thereal to electrical efficiency was used to calculate the power-generation capacity by an equivalent fossilfuel plant, 1.e., the cajulated figure $\left[86 \times 10^{\circ} \mathrm{HN}(\mathrm{e})\right]=[(.02+.05) / 2] \times$ $5 \times 10^{12}$ wates $\times 0.4$.

hiverage of the 5 to $10 \%$ of the total energy requlresents shown in Ref. 9. Calculation similar to that is. footnote $g$.

iverage of 1 to 57 quoted in Ref. 15. Value shown in Table I calculated as in footnote $g$. 
Table II. Fraction of tozal estimated U.S. energy requirements for the year 2000 that night be supplied by solar energy based on averages from Table I

\begin{tabular}{|c|c|c|}
\hline Hethod of supply & $\begin{array}{c}\text { Average of } \\
\text { :stinated capacities }\end{array}$ & $\begin{array}{l}\text { Percentage of } \\
\text { U. S. requirements }\end{array}$ \\
\hline $\begin{array}{l}\text { Heating and coolisis } \\
\text { of bulldings }\end{array}$ & 3.7 quads & \\
\hline Process heat & 1.4 & \\
\hline Organic materials & 6.5 & \\
\hline TOTAL & 11.6 cuads & 77 \\
\hline $\begin{array}{l}\text { Thermal conversion } \\
\text { tu electrictey }\end{array}$ & $36 \times 10^{3} \mathrm{MH}(\mathrm{e})$ & \\
\hline Photovoltaic & 43 & \\
\hline Wind energy & 76 & \\
\hline Ocean thermal & 33 & \\
\hline TOTAL & $188 \times 10^{3} \mathrm{M}(\mathrm{e})$ & 107 \\
\hline
\end{tabular}

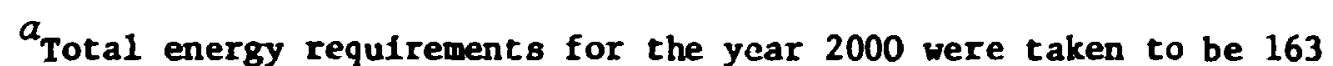
grads (Ref. 21), and the total electrical generating capacity for the year 2000 was taken to be $1887 \times 10^{3}$ M(e) (Ref. 23). 
Although solar energy has the potential for supplying all of our energy needs, even the optimistic data in Table II Indicate that for the midterm ( 2000 A.D.) at least, other resources must be considered.

The data are termed optimistic because it has been tacitly assumed that all of the technological, economic, and institutional problems associated with these systems will be solved early in the time span under consideration. iicy must be solved early in the time span so that the remaining time can be used for the massive implementation of these systems that is required in order to fulf 111 the expectations indicated in Table II.

Furthermore, the solar contributions as viewed by two major federal agencies which are concerned with energy supply have not been included. These agencies are the Department of the Interior and the Federal Energy Administration. Quoting from the former (Ref. 21, p.25),

"The role of solar energy in supplementing other energy sources was difficult to evaluate. It was felt that solar energy wouli not, barring a major technological breakthrough, play any significant role in the production of electricity. (Italics added). However, the household and commerctal sectors may, in the immediage range, successfully exploit solar energy. As solar heating and cooling are capital intensive, jovernment subsidization of solar homes, and the Industry to support this effort, may become necessary. The role solar energy will play in the context of future energy consumption is so dependent on government policy that forecasting its future use was not feasible."

Quoting from the latter (Ref. 22., p. xxxili),

"Solar, geothermal, and synthetic fuels will make only a small contribution to the domestic eneigy supplies by 1985 (about 17)."

"The major contribution from solar, geothermal, and synthetic fuels will not be felt until after 1990."

"Unless comercial size plants are started now and proven economic by 1985 , it will not be possible for these new sources to replace dwindling supplies of 011 and gas in the post-1985 period." 
In the same reference the total projected contribution from solar, gectheral and synthetic fuel in the year 1990 for a reference scenario is (2 quads out of a total of approximately 120, Ref. 11) about 1.77, and for an "under-mst-optinistic-conditions" scenario the prediction is approxinately 6 quads or about 57.

In sumary, wost reports conclude that the wost likely candidates, among the family of solar system, to make an Imact on our energy needs by the year 2000 are those pertalning to space heating and cooling and to organic materials. There is such a great diversity of upinion on the potential impact of the other solar systcms that it would be umise to reject proven system by relying heavily on the anticipaced success of the solar system in question.

POTEATIAL SOLAR SUBSTITUTIOA FOR BASE LOAD TAR's Capac1ty Displacenent

There is a possibility that if the recycling of axt:d oxide fuels is not penfted the projected electrical generating capacity of light water reactors in the year 2000 may have been overestimated. The question to be answered for the irpact statement purposes of the recycling process is, could this potential decrease in nuclear capacity be replaced with solar systens by the year 2000 .

Essentially all of the solar systems that rely on direct converition of the sun's rays, and also lacluding wind systems, are designed to date with lintted storage capabilities. Put another way, heating and cooling systems, process heat, systems involving conversion to electricity by central receivers, distributed collectcis, photovoltaic cells, and wind as presently designed have no long term storage capabilitieg. In this context "long term" storage means a storage system of such capacity that auxiliary systems or standty conventional electrical systems are not needed. Nuclear systems as well as fossil fueled systems are assumed to be conventional.

A11 of the solar sys ms conserve fuel when they are in operation, but when there has beeu no sunshine or wind for a sufficient pertod of time auxillary heaters for space heating and cooling, and standby 
electrical generating systems must be turned on. These solar systens then have not displaced conventional capacity, since the capacity must be avallable at the time that the limited storage capabilities of the solar systens bave been depleted.

There are two ways that capacity can be displaced. One ts the invention and utilization of $\approx$ long term energy-storage systee. Ihe other is the installation of a relatively large number of solar systems at diverse locations. This number and diversity must be large enough so that there would be a high probijllity that at least scme of the systens could be in operation at any tine. Detailed calculations to deternine the ninimumbers and the combinations of solar and wind systems that could displace conventional capacity have not been carried out. In fact, the data necessary for such calculations are only now being processed. ${ }^{26}$ A very approximate calculation (Appendix) Indicates that for a system consisting of $100 \mathrm{M(e)}$ capacity from solar energy in combination with $20 \mathrm{M}(\mathrm{e})$ of capacity from wind, and with both solar and wind units dispersed over the entire United States there would be a 97 to 997 probability that $10 \mathrm{w}(\mathrm{e})$ would be avallable to the U.S. system at any time. Hence, I0 $M(\epsilon)$ of conventional capacity might be displaced for the proposed system, but the implication oz this displacement is, for example in an extreme case, that power generated on the west coast would be readily avaflable on the east coast if needed. The value of the failure-to-meet-demand quoted by industry is one day out of ten years, or a systems rellability of 99.967 .2 : The figures from the approximate calculation are presented only to give an idea of the relatively small leverage that even widely dispersed solar systems would have on capacity displacement, and they are not meant to provide information upon which reasonable judgments car be based. Such fudgments an be made only after the necessary data arc avallable and che detailed calculations carried out.

Another point to be made is that a study by the Aerospace Corpusation indicates that the operation of central receiver solar energy $p$ lants could be more competitive (rompared to conventional plants) if they were intended to supply intermediate load electricity. ${ }^{2}$ They would be far less competitive for base load or peak load applications. This study indicates therefore, that even if solar central station power plants are 
eployed, it is more likely, on the basis of econonic considerations, that they would be used to supply internediate laad electricity and they would not likely supplant LWR's, which supply base load power. The lifelihood that an econonically feasible long-tern storage systen will be invented in tive to be useful is completely uncertain. Sufficient to say that the funding for research in storage systens is not considered part of the ERDA solar energy progran at the present time.

of the two remining solar systems not discussed above, l.e., ocean thermal systems and organic naterials, the latter will not displace conventional capacity, because one of its primary objectives is the production of fuel. The other objective is the disposal of wastes.

Ocean thermal conversion, then, is the only solar gysten remaining that could directly displace conventicnal capacity. Using the average value of the optinistic projections of Table $I\left[33 \times 10^{3} \mathrm{M}(\mathrm{e})\right]$, ocean thermal systems might displace approximately $7 \pi$ of the anticipated nuclear capacity [507 $\left.\times 10^{3} \mathrm{~N}(\mathrm{e})\right]$ by the year 2000. However, it is anticipated that ocean therwal electric systems will also be applied to processes other than the production of base load electricity. These are the production of hydrogen, amonia for fertilizers, aluminum, and/or other energy intensive products. ${ }^{29,30}$ If such applications are realized, the predicted capacity displacement would be saduced.

There are many serious technological problems that must be overcome before large scale utilization of ocean thermal systems can occur. These problems are described in a subsequent section. Since research and development on these systems is only now being undertaken, it would not seem prudent to rely on the large scale implementation of these systems to replace the capacity of systems already proven.

To sumarize, because of the intermittency of the sun and wind and In the absence of a long-term energy-storage system, all of the solar systems under discussion except one require gtandby capacity of a size equal to the size of the solar system. Each Individual system thus saves fuel but does not replace conventional capacity. A mixture of dispersed solar systems might replace some capacity, but the ratio of capacity displaced to total solar system size is small. Rellable quantitative estinates of this ratio must await the accumulation of the pertinent 
weather data and the performance of detailed calculations. Indicaticns are that solar central station power plants are most econowic is applied to internediate load electricity, and hence they are not likely to replace. base load LWR's. On a relative scale, funding for R\&D in energy storage systems is small, hence majcr breakthroughs in this area are not likely. Such a breakthrough would be required for the individual solar systems to replace conventional capacity. The ocean thermal systen is the only solar system that relies on a stable source of energy, i.e., the temperature difference between surface and deep ocean water, and it is the only one that could displace conventional capacity without storage. Optimistic estimates of the installed capacity of these systems by the year 2000 represent 77 of the estimated nuclear capacity for that year. However, the anticipated use of these plants includes the production of enersy intensive products in addition to the production of electricity, and hence the 77 is an overestimate of the capacity displacement. In order to fulf 111 the $7 \%$ requirement thirty-three $1000 \mathrm{MH}(\mathrm{e})$ plants must be built offshore in the next 25 years. Considering the fact that there are many unresolved problems associated with these systems, which are just now recelving attention, it does not appear frudent to rely on the displacement of conventional capacity by these systems.

In conclusion, it appears unlikely that solar energy will displace even as much as $5 \%$ of the anticipated nuclear capacity by the year $200 \mathrm{C}$.

\section{Economic Considerations}

\section{Effect of recycling option on solar economics}

The discussion in this section wil be restrlcted tr. econowics alone, and the subject that will be explored is the following: the cost of electricity consists of three separate parts, the princlpal and interest charges on the capital investment, the operation and maintenance charges, and the cost of fuel. The sum of these costs over a one year perlod divided by the electrical energy delfuered during the year is the cost per $\mathrm{kWh}$ of the electricity. Solar syst ms do not burn fuel, and so the cost of elcctricity from these systems consists of only the first two of the 
three comonents. Given sone assuned price of electricity, it is a simple mater to work backwards and calculate the capital investment of the solar system that woudd be required to produce electricity at that price. The capital cost of the solar systen 18 therefore established as a competitive target by the cost of the electricity wich is produced by conventional ceans.

It 18 pertinent to the generic ispact statement for the Pu recycling process to estimate the Imact that recycling may have on this competitive target capital cost of solar systens.

The difference in electrical energy costs with and without Pu recycling 18 estimated to be $0.5 \mathrm{w} 11 \mathrm{~g} / \mathrm{kWh} .{ }^{31}$ The capacity factor for solar systems is assuned to be the same as that for IKR's, ${ }^{32}$ navely 0.65 , and the fixed charge rate on the capital investment 18 taken to be $15.5 \%$, and the annual operating and maintenance charges are taken as 1.57 of the capital investment. Then the difference in the target capital costs, $\Delta C$, for solar systems if they are to be competitive with LWR's with and whthout recycling is calculated to be

$$
\Delta C=\frac{0.5 \mathrm{mil1s} / \mathrm{kHh} \times .65 \times 8760 \mathrm{hrg} / \mathrm{gr} \times 10^{-3} \mathrm{~s} / \mathrm{mL11}}{(.155+.015) / \mathrm{yr}} \simeq 17 \$ / \mathrm{kH}
$$

Eslimates of the capital costs of solar systens vary considerably. For example, in one study ${ }^{33}$ the cost varied from $2150 \$ / \mathrm{kW}(e)$ to $1730 \$ / \mathrm{kW}(e)$ depending on the receiver, while in another ${ }^{34}$ the cost was $1223 \$ / \mathrm{kW}$ wh a somewhat different recelver.

In conclusion, the small difference in the cost of generating electricity with and without Pu recycle will make an Insignificant difference In the target costs for solar energy systems in order that they be courpetitive.

\section{Protected Solar Costs}

At the present time, the primary obstacle to the large scale utilization of solar energy is the cost of the systems, for there are no fundamental unanowered questions concerning their ability to operate. An 
exception to this is the blomass process, because in many locatiors this process can conpete with present methods of waste disposal (land f111s). A study of the projected costs of solar systems vs converiflonal. systems was carried out by the Mitre Corporation, ${ }^{35}$ and the results are suarized in terns of an Economic Viability Ratio. This is defined as the ratio of the total annual costs of typical solar energy systems to correspoadiag conventional systers using fossil fuels. The results of their study are shown in Table III orojected to the year 2000 .

Inherent in these projections is the assurstion that the major known problems and pocential problews assoclated with the technoiogy of these systems w11 have been favorably resolved.

Table III. Projected economic viability ratio (solar/conventional)

\begin{tabular}{lll}
\hline & 1985 & 2000 \\
\hline Heating and cooling & 1 to 1.5 & 1 to 1.25 \\
Process heat & 1.5 to 2 & 1 to 1.5 \\
Solar-thermal & 2.5 to 3 & 2 to 2.5 \\
Ocean thermal & 1 to 1.5 & 1 to 1.25 \\
Photovoltaic & 6 to $>10$ & 1 to 4 \\
Wind & $\sim 1$ & $\sim 1$ \\
Organic materials & $\sim 1$ & $\sim 1$ \\
\hline
\end{tabular}

LAND USE OF SOLAR VS NUCLEAR

The unit of land-use that will be ut 111 zed for the comparison of the land used by solar vs that used by nuclear systems is the acre-year, which 18 defined as the use of one acre for one year. In the GESMO Report $^{36}$ the land-use value for $11 \mathrm{ght}$-water reactors (no recycling) for the years 1975 through 2000 is reported to be $2.8 \times 10^{7}$ acre-years. Recycling affects this figure by 1 ess than $20 \%,{ }^{36}$ and 1 will be shown that this 207 variation is of small fmportance to the discussion. 
During the same 25-year period, cumlative electrical energy generated. from nuclear reactors 13 estimated to be $35 \times 20^{12} \mathrm{kWh}(\mathrm{e}) .^{37}$

In comparing the land use value for solar systens, it will be assuned that each system would generate $30 \times 10^{12} \mathrm{kWh}(e)$ over the same 25-year time span.

\section{Solar Thermal (Central Recelver)}

It is estimated that a $100 \mathrm{MH}(e)$ power plant with sufficient storage capacity to operate up to 6 hours in the evening (in addition to daytine operation) would occupy an area of 2.4 square miles or $1.5 \times 10^{3}$ acres. ${ }^{30}$ The design-point solar flux for this systen would be avallable 2000 hours out of the year. ${ }^{39}$ The 2000 hours of sunshine per ytar represents an average of $5.5 \mathrm{hrs} /$ day. The storage facility for this plant is designed to delfver 6 hours of electrictty at 707 load in the evening for every 6 hours of design point sunshine. Since this sunshine is avallable approximately $6 \mathrm{hrs} / \mathrm{day}$ on the average, and the plant is operating at full power during this period, it will be optimistically assumed that the plant will deliver 2 hours of electricity for each hour of sunshine. The assumption $f_{3}$ optimistic because it assumes a perfect match between the insolation and the 6 hour storage capabilities. On days when the design point flux is avaslable for a perfod longer than 6 hours the plant will st111 deliver only 6 hours of electricity in the evening. Furthermore, it is assumed that the electricity generated from storage is at full load, rather than $70 \%$ load.

The deliverable electrical energy (per acre) in one year for a plant of this type is calculated to be

$$
\begin{gathered}
100 \mathrm{MH}(\mathrm{e}) \times \frac{2 \mathrm{hrs} \text { delivery }}{1 \mathrm{hr} \text { sunshine }} \times 2000 \frac{\mathrm{hrs} \text { sunshine }}{\mathrm{yr}} \times 10^{3} \frac{\mathrm{kW}}{\mathrm{MW}} \\
\times \frac{1}{1.5 \times 10^{3} \text { acres }}=2.7 \times 10^{5} \frac{\mathrm{kWh}(\mathrm{e})}{\mathrm{acre} \mathrm{yr}} .
\end{gathered}
$$

The land-use for plants or this type, If they were avallable to generate the total cumulative electrical ener,zy to be supplied by nuclear power plants to the year 2000 , is then 


$$
\frac{35 \times 10^{12} \mathrm{kWh}(e)}{2.7 \times 10^{5} \mathrm{kWh}(\mathrm{e}) / \text { acre year }}=13 \times 10^{7} \text { acre years. }
$$

\section{Photovoltaic}

In an attempt to characterize a generic photovoltafc eiectricalpower producing plant located in the southwest, the following assumtions were made: $* 0$

Net systens efficiency

87.

Total insolation $2300 \mathrm{kWh}(\mathrm{e}) / \mathrm{m}^{2}-\mathrm{yr}$

Fraction of land covered by collectors 357

The product of these factors gives a power density (pover/land area) of $64 \mathrm{kWh}(e) / \mathrm{m}^{2}-\mathrm{yr}$ or $2.6 \times 10^{5} \mathrm{kWh}(e) /$ acre-yr.

In supplying the electrical energy expected from nuclear pover for the next 25 years the Iand use factor is calculated as

$$
35 \times 10^{12} \mathrm{kWh}(\mathrm{e}) / 2.6 \times 10^{5} \frac{\mathrm{kWh}(\mathrm{e})}{\mathrm{acre}-\mathrm{yr}}=13 \times 10^{7} \text { acre years. }
$$

\section{Windmills}

The rotor diameter of a windmill designed to generate a power of $1.5 \mathrm{M}(e)$ for wind speeds of about $25 \mathrm{mph}$ is assumed to be $180 \mathrm{ft} .1$ The plant factor ${ }^{+1}$ is taken to be 0.43 . If a field of these mills vere set up such that each windmill was at least six rotor diameters (D) apart, which is sufficient to prevent the turbulence from one sindmill to affect another, and the smallest reproductble geometric sub-unit of the field is taken to be a triangle with sides of length $D$, then the electrcal energy per untt area of such mills is given by

$$
\begin{aligned}
\frac{1500 \mathrm{~kW}(e) \times .43 \times 8.76 \times 10^{3} \frac{\mathrm{hrs}}{\mathrm{yr}} \times 5.28^{2} \times 10^{6} \frac{\mathrm{ft}^{2}}{\mathrm{mile}^{2}}}{(6 \times 180)^{2} \mathrm{ft}^{2} \times \cos 30^{\circ} \times 640 \mathrm{acres} / \mathrm{mile} \mathrm{e}^{2}} \\
\quad=2.4 \times 10^{5} \frac{\mathrm{kWh}(\mathrm{e})}{\mathrm{acre} \mathrm{yr}} .
\end{aligned}
$$

This is based on the fact that the density per unit area of objects placed on the corners of the trlangles in a large fleld of adfoining 
fsosocles triangles is given by the sum of the fractional contributions of each object at each corner of the triangler $\left(3 \times \frac{60}{360}\right)$, divided by the area of the triangle $\left(\frac{1}{2} D^{2} \cos 30^{\circ}\right)$. The land-use of these systems if they were to replace the power expected from nuclear reactors over the next 25 years is

$35 \times 10^{12} \mathrm{kWh}(e) / 2 . \dot{4} \times 10^{5} \frac{\mathrm{kWh}(e)}{\operatorname{acre} \text { year }}=15 \times 10^{7}$ acre years.

These results are sumarized in Table IV.

Table IV. Comparative solar system land-use in supplying the cumulative net power expected from nuclear power plants $\left[35 \times 10^{12} \mathrm{kWh}(\mathrm{e})\right]$ from $1975-2000^{a}$

\begin{tabular}{lcc}
\hline \multicolumn{1}{c}{ Plant type } & $\begin{array}{l}\text { Power per unit area } \\
{[\mathrm{kWh}(\mathrm{e}) / \text { acre-year }]}\end{array}$ & $\begin{array}{c}\text { Land-use } \\
\text { (acre year) }\end{array}$ \\
\hline $\begin{array}{l}\text { Light water reactors } \\
\text { Solar hermal } \\
\text { Central receiver }\end{array}$ & $2.7 \times 10^{5}$ & $2.8 \times 10^{7 b}$ \\
$\begin{array}{l}\text { Photovoltaic } \\
\text { Windmills }\end{array}$ & $2.6 \times 10^{5}$ & $13 \times 10^{7}$ \\
\hline
\end{tabular}

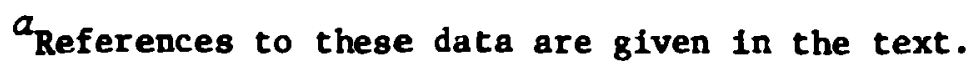

$b_{\text {Land }}$ use without $\mathrm{Pu}$ recycle. With $\mathrm{Pu}$ recycle it is approximately 2021 less (Ref. 36).

The data indicate that under the conditions assumed for this comparison that nuclear energy 18 expected to be considerably more efficlent in land-use than the solar systems that were studied, and therefore the consideration of the land uged by solar vs that used by nuclear systems has little relevance in the discusston of solar energy as an alternate source of energy in GESMO. 
RELATED SUBJECTS ON SOLAR ENERGY

\section{Technical Problems}

The technical problens associated with each of the solar systems are described below.

\section{Heating and cooling}

Sensitivity to dirt on the cover plates, susceptability of these plates to breakage, unknown lifetime for the system, durability of selective coatings under high temperature operation, iack of an efícient method for cooling.

\section{Process heat}

Unknown lifetimes, inadequate storage for high temperature systems, corrosiveness of saline water when such is utilized (as in solar ponds).

\section{Solar thermal conversion to electrialty}

Unknorm boiler lifetimes, unknown reflector lifetimes, reliability of lazge numbers of tracking systems, tharmal stresses and thermal cycling, maintenance of high vacuums under high temperature (distributed collector system), solidification of high temperature fluids, effecis of weather and dust on heleostats.

\section{Photovoltaic}

Low efficiencies (approximately $10 \%$ at present), unknown iffetime, weather and dust effects, rellability at operating temperatures. 
Wind energy

Cyclic stress effects, response of large systems to changing wind directins (horozontal shaft machines), response to sudden wind speed changes.

Ccean thermal

Efficiencies at low $\Delta T$, reliability of massive heat exchangers, effects of the corrosive environment, stress-strain effects of ocean currents on enorwous coid water intake pipe, parasitic power pumping losses, biofouling, underwater maintenance, transmission of electricity over long distance underwater.

\section{Environmental Problems}

In general, the environmental problems for most of the systems are thought to be small. The systems for which few environmental problems are envisioned are heating and cooling of buildings, process heat and the limited use of photovoltaics. An example of the latter is the use of photovoltaics as a supplemental source of electricity for homes.

Even when large land areas are covered in the production of central station electricity, either for solar theimal systems or for photovoltafc cells, the environmental problems are thought to be minimal. The location of these systoms in desert regions might result in some reduction in the population or animal species which are dependent on the climate peculiar to the desert. On the other hand, flora and fauna that exist marginally in trose regions, because of the intense heat, may flourish in the vicinity of the power plants. The aesthetics of these large systems leave much to be desired, but it is unlikely that their implementation w11 be inhibited for this reason only.

Windmills capable of producing large quantities of electricity [approximately $1000 \mathrm{MH}(\mathrm{e})]$ are not under serious consideration. Therefore, many small systems must be employed for the electrical production of significant magnitudto. THe effects on the weather of these systems 
is uncertain, but serious problems in this rezard ars not anticipated. The noise that present systems prodice will raise objections in large fields of windmills, and noise abatement for windmills is unde: investigation. Aesthetics are a potential problem but arc unlikeiy to be serious.

The employment of many ocean thermal systems will disturb the downstream cemperature gradients of the ocean. The magnitude of the problem is uncertain at the present time.

\section{So:-ial and Institutional Problems}

There are fev social problems anticipated; however, there are serious institutional problems that must be resolved before large scale solar energy utilization can take place. fmong the most importint of these problems are:

1. the legal rights of exposure to the sun, so that others may not obstruct the sun from reaching the collectors,

2. high capital costs which result in probjems of financing,

3. use of large land areas and competing lind use,

4. "wind rights" such as in 1 ,

5. Industrial and safety codes,

6. zoning restrictions,

7. establisinment of standards,

8. International law regarding ocean thermal plants, and

9. the security of these plants from sabotage.

CONCLUSION

It is concluded that the role of solar energy should have little effect on the considerations pertaining to GESMO. 


\section{APPENDIX}

The problem is to calculate the probability for a combination of solar-electric and wind systeas of baving some fraction of the total power avallable at any time. If this probability is very high, then the electrica! poner industry could displace a corresponding anount of capacity with this specified fraction, since the industry could assine that this fraction 18 essenţlally alvays avallable. A systens - rellability quoted by Industry 18 that corresponding to a 1 day fallure-tomeet-denand out of 10 years, or a probability of success in meeting denand of 99.967 .27

A firat-estimate method of calculating the desired quantity is as follows: assume a widely dispersed (over the entire U.S.) solar-electric aysten with a total capacity of $100 \mathrm{MH}(\mathrm{e})$ and with overnight storage capabilities such that a full day of sunshine will store sufficient energy to generate full capacity throughout the night. The demand on the systen is assumed to be constant for simplicity. Along with the 100 W(e) solar, assure a wind-electric system similarly dispersed with a total capacity of $20 \mathrm{~m}(\mathrm{e})$ and no storage. Out of a total capacity of $120 \mathrm{KN}(e)$, an arbitrary amount, say $10 \mathrm{kN}(e)$, will be selected, and the probabllity that at least this $10 \mathrm{MH}(\mathrm{e}) \mathrm{w} 1 \mathrm{l}$ be avallable at any the from the entire system wil be calculated.

\footnotetext{
Let $p_{8}(x) d x=$ probability that the power avallable $a=$ any time from the solar system lies at a value within dx about $x$

$P_{w}(y) d y=a$ similar definttion for the wind system,
}

wth

$$
P_{8}(0) \neq 0, P_{w}(0) \neq 0
$$

and

$$
P_{8}(x>100)=P_{w}(y>20)=0
$$


37

along with

$$
\int_{0}^{200} p_{s}(x) d x=\int_{0}^{20} p_{w}(y) d y=1
$$

Since data for these distribution functions are not yet avallave, some not unreasonable assumptions will be made, namely that for the solar system the probability that at least $10 \mathrm{MN}(\mathrm{e})$ is available at any time 18 assumed to be equal to the fraction of the days out of the year that clouds wiI cover 902 or less of the entire U.S. This number is estimated to be $340 / 365$, or 0.93 , 1.e.

$$
\int_{10}^{100} p_{8}(x) d x=0.93 \text {, and hence } \int_{0}^{30} p_{8}(x) d x=0.07
$$

Wind systems are presently designed to operate at wind speeds of approximately $15 \mathrm{M} / \mathrm{hr}$ or greater, and it will be arbitrarily assumed that at any time at least half the power is available from the wind system with a probability of 507 , 1.e.

$$
\int_{10}^{20} P_{w}(y) d t=0.50, \text { with } \int_{0}^{10} P_{y}(y) d y=0.50
$$

Assuring complete independence between the solar ind wind systems and also complete independence among the various constituents of the solar system and of the wind systems, the probability that at least $10 \mathrm{MW}(\mathrm{e})$ will be available at any time from the entire system, $\mathrm{P}(\geq 10)$, is then

$$
\begin{aligned}
P(\geq 10) & =\int_{10}^{100} p_{s}(x) d x \int_{0}^{10} p_{w}(y) d y+\int_{0}^{10} p_{s}(x) d x \int_{10}^{20} p_{w}(y) d y \\
& +\int_{10}^{100} p_{s}(x) d x \int_{10}^{20} p_{w}(y) d y
\end{aligned}
$$




$$
\begin{aligned}
& +1 / 2\left[\int_{0}^{10} p_{s}(x) d x \int_{0-x}^{10} p_{w}(y) d y\right. \\
& \left.+\int_{0}^{10} p_{w}(y) d y \int_{10-y}^{10} p_{s}(x) d x\right]
\end{aligned}
$$

The tern in brackets represents the contribution to the probability from the cases where the power avallable from either system is below $10 \mathrm{kH}(\mathrm{e})$, but the sum of the power from each system equals or exceeds 10 M(e). To save tedious rewriting, this contribution will be termed G. Substituting the assumed values for the integrals into the expression,

$$
P(\geq 10)=0.965+G
$$

One can get an overestimate of $G$ by the following considerations: the $p^{\prime} s$ for the wind and solar will very likely have the form

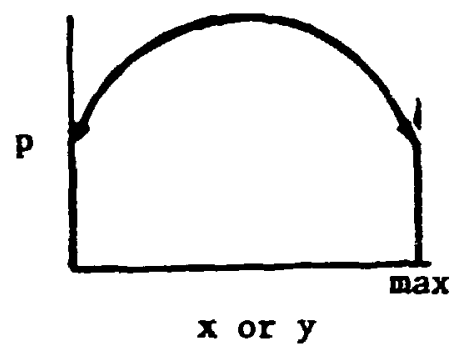

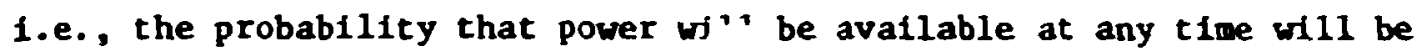
relatively small for zero power an. so for maximum power, and it will be greatest somewhere in between the two extremes. If one then assumes that each of the distribctions are uniform, i.e., If one assumes that $p_{s}(x) d x=d x / 100$, and $P_{w}(y) d y=d y / 20$, which represent straight hor $1-$ zontal lines with values $p_{s}(x)=1 / 100$ and $p_{w}(y)=1 / 20$, these values at the low end of the scale should be greater than the true values. Utilizing the uniform values 


$$
G=1 / 2\left[\int_{0}^{10} \frac{d x}{100} \int_{10-x}^{10} \frac{d y}{20}+\int_{0}^{10} \frac{d y}{20} \int_{10-y}^{10} \frac{d x}{100}\right]=0.25 .
$$

When added to the expressiun for $P(\geq 10)$, the sum fives an estimate of the desired overall probability as

$$
P(>10)=0.990
$$

with in fact

$$
.965<P(\geq 10)<0.990
$$

\section{REFERENCES}

1. "Final Generic Environmental Statement on the Use of Recycle Plutonium in Mixed Oxide Fuel in Light-Water Cooled Reactors," NUREG-0002, Vo1. 1, PP. ES19-20 (August 1976).

2. GESKO hearing board, "Order Concerning Questioning of NRC Staff, Supplementing Final GESMO-1, and Other Hearing Procedures."

3. Ref. 1, Vol. 2, Pp. III-31.

4. A. B. Meinel, "Solar Energy for the Terrestrial Generation of Electrtcity," Hearing befcre the Subcomittee on Energy of the Committee on Science and Astronaut1cs, U.S. House of Representatives, 93rd Congress, First Session, June 5, 1973, No. 12.

5. J. Yellot, "Energy from the Sun," Power Eng., February 1957.

6. "Central Receiver Solar Thermal Power System - Phase 1; Summary Progress Report Apr1l 1976," Martin Marletta, The Bechtel Corporation, Foster Wheeler Engineering Experimental Station, Georgia Institution of Technology, Report No. MCR-76-121.

7. "A Preliminary Technological and Economic Assessment of Solar PowePlants Using Line Concentrators," 900-704, EM 342-302, Jet Propulsion Litoratory, California Institute of Tectmology, Pasadena, Califernia, prepared by Kudret Selcuk, Thermal Energy Conversion Grc:!r. (July 1975).

8. "Assessment of Photovoltaic Power Conversion System for Central Station App11cation," 900-702, EM 342-294, Jet Prupulsion Laboratory, California Institute of Technology, Pasaderia, California, prepared by Charles R. Bell, Thermal Energy Conversion Group (June 1975). 
9. "Subpanel IX - Solar and Other Energy Resources," prepared for the Chairnan of the USAEC. A. J. Egger 8, Jr., Subpanel Chairuan, National Science Foundatior, October 27, 1973, p. 72.

10. "Technical and Econonic Feasibilicy of Ocean Thermal Energy Conversion," G. L. Dugger, E. J. Francis, and W. H. Avery, Applied Physics Laboratory, John Hopkins University, Report AEO-76-060 (August 1976).

11. "Solar Energy: A View Fron an Electric Utility Standpoint," Drain F. Spencer, Kanager Solar and Geothermal Prograns, Electric Power Research Institute, Anerican Power Conference, Chicago, Illino1s, April 21-23, 1975, No. 104.

12. "A National Plan for Energy Research Developaent and Dewonstration: Creating Energy Cholces for the Puture," ERDA-48, Vo1. 1, P. B4.

13. "liational Solar Energy Research, Development; and Demonstration Program," ERDA-49, p. I-4, June 1975.

14. "A National Plan for Energy Kesearch, Development and Denonstration: Creating Energy Cholces for the Puture," ERDA-76-1, Vol, 1, p. 7, April 16, 1976.

15. "Systems Analysis of Solar Energy Programs," Mitre Corporation Report MIR-6513, p. xix, December 1973.

16. Ref. 11, p. 11 .

17. Ref. 12, Vol. 2, p. 33 .

18. Ref. 11, p. 20 .

19. Ref. 11, p. 28 .

20. Rei, 12, Vol. 2, p. 29.

21. "Energy Through the Year 2000 (revised)," W. G. Dupree, Jr., and J. S. Corsent1no, Bureau of Mines, U.S. Department of Interior, p. 6, December 1975 .

22. "National inergy Outlook," Pederal Energy Administration Report No. PEA-N75/713, p. Xxiv, February 1976.

23. Ref. 21, P. 36 .

24. H. C. Hottel, "Challenges in Production of Fossil Fuels," Chem. Eng. Progr., 68 (6), 36 (June 1973).

25. Testimony of G. Lof, Hearing before the Subcomattee on Energy of the Comittep on Science and Astrorautics, U.S. House of Representatives (June 7, 1973). 
26. Lester Machta, National Air Resources Laboratory, Silver Springe. Maryland, private commication to H. H. iertini, Oak RIdge National Laboratory, December 10, 1976.

27. "The Economics of Reliability for Electri= Generating Systems," M. L. Telson, Massachusetts Institute of Technology, Report No. MIT-EL 73-016 (May 1973) pp. 118-127.

28. "Solar Thermal Conversion kission Analysis, Summary Report, Southwestern United States," Vol. 1, Fuergy and Resourses Division, The Aerospace Corporation, El Segunds, California, Repor: No. ATR-74(7417-16)-2, pp. 174-181 (January 1975).

29. Ref. 14, Vol. 2, p. 108.

30. "Technical and Econonic Feasibility of Ocean Thermal Energy Conversion," G. L. Dugger, E. J. Francis, and W. H. Avery, Applied Physics Laboratory, Johns Hopkins University, Report No. AE0-76-060, p. 2 (August 1976).

31. Ref. 1, Vo1. 4, p. xi-5, footnote.

32. Ref. 21, Table 15, p. 36 .

33. Ref. 7, p. 64.

34. "Dynamic Conversion of Solar Generated Heat to Electricity," J. D. Powe11, et al., NASA CR-13/724 p. 206 (August 1974) Honeywell Incorporated, Systems and Research Center, Minneapolis, Minnesota, and Black and Veatch, Consulting Engineers, Kansas City, Missouri.

35. Ref. 15, p. xx.

36. Ref. 1, Vol. III, Tüble IV A-7, P. Al0.

37. Ref. 1, Vol. I, P. ES-4.

38. Ref. 6, Fig. I-7, P. I-12.

39. "Solar Power Array for the Concentration of Energy," Semiannual Progress Report covering the period 1 January to 30 June 1974," (July 31, 1974) NSF/RANN/SE/GI-41019/PR/74/2, p. 166. Prepared by Sheldahl, Inc., Poster Wheeler Corporation and the University of Minnesota.

40. Ref. 8, p. 4.

41. "Supplemental Testimony on Contention I-22(h)," by Howard A. McLain, April 14, 1976, before the Atomic Safety and Licensing Board, USNRC, in the matter of Kansas Gas and Electric Company and Kansas City Power and Light Company (Wolf Creek Generating Station, Unit mo. 1) Docket No. 50-482, Attachment B. 